Document downloaded from:

http://hdl.handle.net/10251/48351

This paper must be cited as:

Alfalla-Luque, R.; Marín García, JA.; Medina-Lopez, C. (2015). An analysis of the direct and mediated effects of employee commitment and supply chain integration on organisational performance. International Journal of Production Economics. (162):242-257. doi:10.1016/j.jpe.2014.07.004.

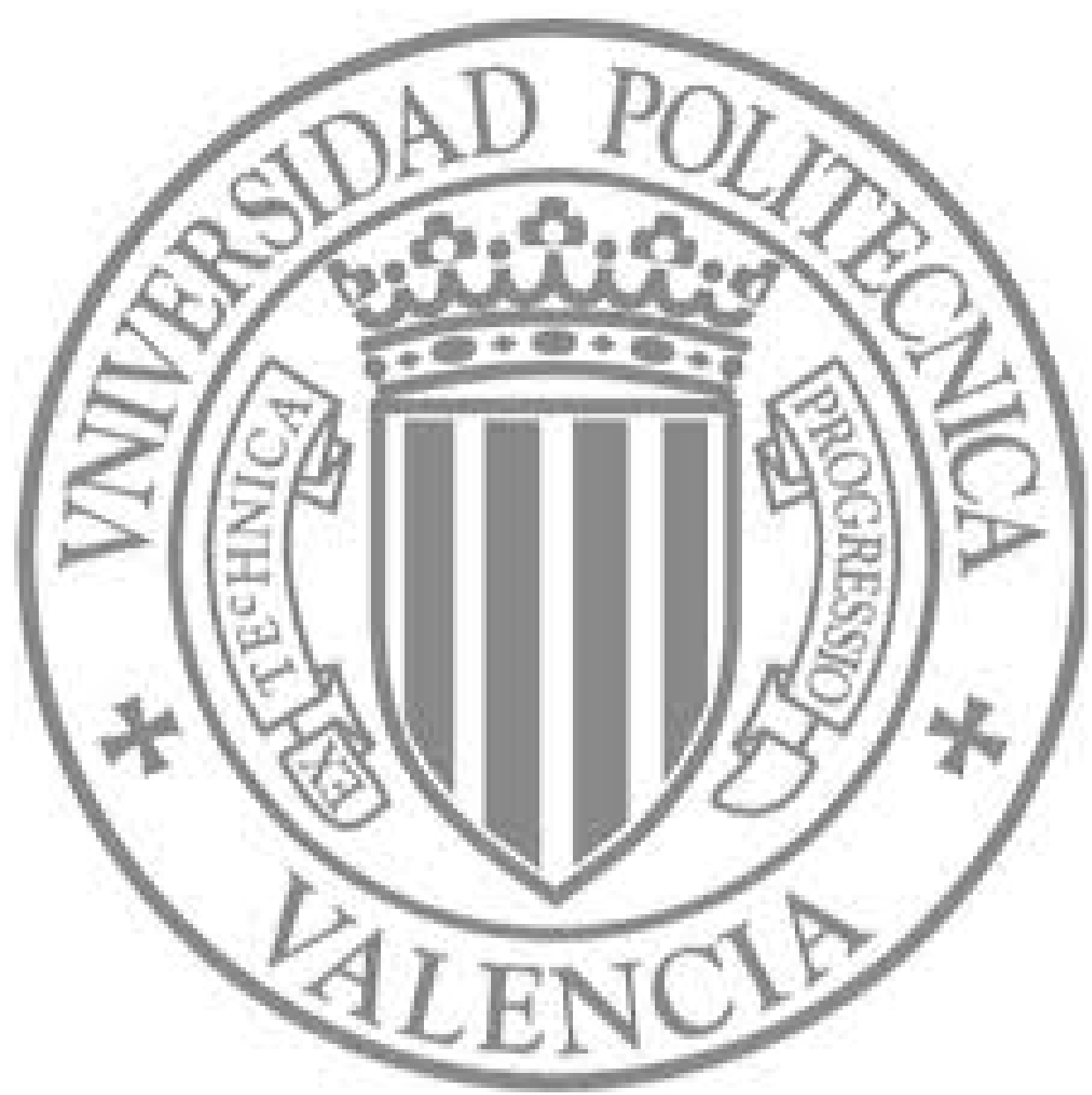

The final publication is available at

http://dx.doi.org/10.1016/j.ijpe.2014.07.004

Copyright Elsevier 
An analysis of the direct and mediated effects of employee commitment and supply chain integration on organisational performance

\author{
Rafaela Alfalla-Luque ${ }^{1}$ \\ University of Seville \\ Juan A. Marin-Garcia ${ }^{2}$ \\ Polytechnic University of Valencia \\ Carmen Medina-Lopez ${ }^{3}$ \\ University of Seville
}

${ }^{1}$ GIDEAO Research Group. Departamento de Economía Financiera y Dirección de Operaciones. Universidad de Sevilla. Avda. Ramón y Cajal, 1. 41005. Sevilla. Spain. Tel.: 00.34.954.556.456. Fax: 00.34.954.557.570. Email: alfalla@us.es

2 Email: jamarin@omp.upv.es

${ }^{3}$ Email: cmedina@us.es 


\title{
An analysis of the direct and mediated effects of employee commitment and supply chain integration on organisational performance
}

\begin{abstract}
This paper focuses on the interrelationships between the different dimensions of supply chain integration. Specifically, it examines the relationship between employee commitment and supply chain integration dimensions to explain several performance measures (flexibility, delivery, quality, inventory and customer satisfaction). Very little research has been conducted into this topic, since employee commitment is rarely included as an antecedent of the effect of supply chain integration on performance. Seven research models have been analysed with Structural Equation Models using a multiple-informant international sample of 266 mid-to-large-size manufacturing plants. The findings suggest that the relationship between employee commitment and operational performance is fully mediated by supply chain integration. Employee commitment contributes to improving internal integration, and internal integration affects performance both directly and indirectly. Moreover, obtaining internal integration helps to achieve supplier and customer integration. As a result, companies should strive to achieve both employee commitment and internal integration, as they mutually reinforce each other. Similarly, managers should achieve internal integration before external integration and include external integration at the strategic level in order to reap the greatest advantages from supply chain integration. Meanwhile, managers should promote employee commitment not only for better supply chain success, but also to mitigate the barriers of supply chain management implementation.
\end{abstract}

Keywords: Supply Chain Integration, Commitment, Performance, Mediation

\section{Introduction}

Supply chain management (SCM) has strategic relevance because increased competitive pressures have pushed many firms to turn their supply chains into competitive weapons to enhance performance (Fine, 1998). Effective SCM is a source of potentially sustainable competitive advantage for organisations and supply chain integration (SCI) plays a crucial role in this (Van der Vaart \& Van Donk, 2008). However, despite the potential benefits of SCI, the effective integration of value-added activities along the supply chain (SC) and the competitive influence of SCI have been questioned. Thus, more empirical research is needed in this topic (Leuschner et al., 2013).

Despite the fact that numerous studies have addressed SCI, it can be seen that it is not a well-defined concept (Fabbe-Costes \& Jahre, 2008). SCI does not have a single, accepted definition or operationalisation (Pagell, 2004). SCI should consider the strategic, tactical and operational levels. SCI could be defined as the degree to which SC members achieve collaborative inter- and intra-organisational management on the strategic, tactical and operational levels of activities (and their corresponding physical and information flows) that, starting with raw materials suppliers, add value to the product to satisfy the needs of the final customer at the lowest cost and the greatest speed (Alfalla-Luque et al., 2013b).

SCI needs both intra and inter-company integration across the entire SC in order to work as a single entity (Alfalla-Luque \& Medina-Lopez, 2009). In consequence, SCI research should take into account internal integration (INTI) and external integration (EI) with supplier (SI) and customer (CI), as well as the external integration orientation (EIO).

However, previous research has not always taken the different dimensions of SCI into account (FabbeCostes \& Jahre, 2008). Drogue et al. (2004) suggest that the joint use of EI and INTI has a synergistic effect on firm performance. Other studies show that one of the reasons that prevents a high level of EI being achieved is a low level of INTI (Gimenez \& Ventura, 2005). Moreover, INTI seems to be the starting point for broader integration across the SC. However, there is over emphasis on customer integration (CI) and supplier integration (SI) alone, excluding the important central link of INTI (Flynn et al., 2010). As stated in Zhao et al. (2011), despite increasing research interest in SCI, we still have a very limited understanding of what influences SCI and what the relationships between INTI and EI are. This paper seeks to provide empirical evidence on this relationship.

The prior literature is not unanimous in stating that the relationship between SCI and performance is positive. Some papers conclude that a higher level of SCI positively influences performance (Li et al., 2009), but others have not been able to demonstrate this relationship (Swink et al., 2007). So, additional research is necessary to test the relationship between SCI (separated out into its various dimensions) and performance. This relationship could be affected by the existence of variables that act as antecedents. Some studies have 
found that SCI has a mediating effect on performance (Vanichchinchai, 2012), but a limited number of studies have been conducted in this respect. As a result, determining the antecedents and performance consequences of SCI is a key focus of recent SCM research (Droge et al., 2012).

The apparent inconsistency in the findings and doubt about the relationship between SCI and performance suggest a missing variable. Taking into account the literature, our interest lies in including employee commitment (EC) as an antecedent in this relationship. Previous research has analysed the effect as an antecedent of workforce practices on performance for some operations management (OM) practices, e.g., TQM, JIT and TPM (Cua et al., 2001) but little research has been done into the effect of workforce practices in SCI, or even in SCM in general (Fisher et al., 2010). However, Fawcett et al. (2008) state that human nature is the primary barrier to successful SC collaboration both internally and with external SC partners.

This paper therefore focuses on the relationships between the different dimensions of SCI themselves, and on the relationship between EC and the SCI dimensions to explain several performance measures. It analyses EC as an antecedent of the effect of SCI on performance. For this we use a multiple-informant international sample originating from the third round of the High Performance Manufacturing (HPM) project. Figure 1 shows the research framework.

The paper is structured as follows. Section 2 establishes the theories supporting the research, analyses earlier studies and establishes the hypotheses, objectives and proposed model to be tested. Section 3 describes the sample and the methodology employed. This is followed by the results of the study. Finally, the discussion, main conclusions, contributions, implications for practitioners and academics, limitations and future research are presented.

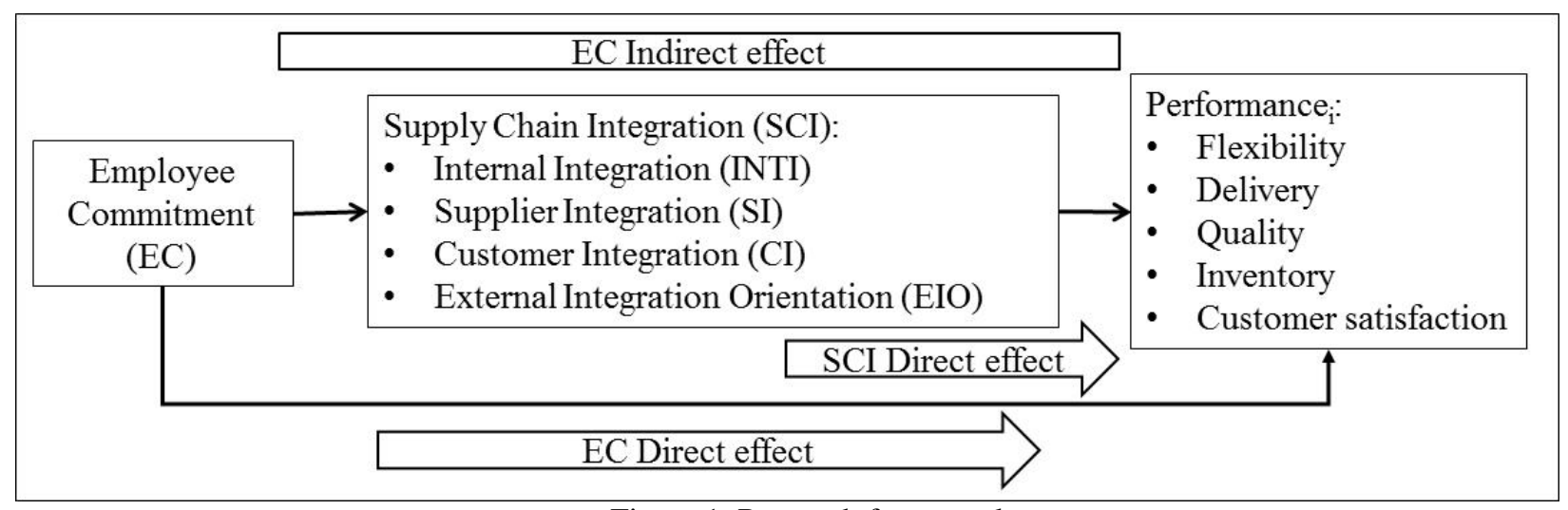

Figure 1. Research framework

\section{Theoretical background, research hypotheses and proposed model}

In this section, firstly an analysis is conducted of the theories that support the research (sub-section 2.1). Next, the relationship between performance, SCI and EC is analysed and seven sets of hypotheses are established on the basis of a thorough literature review. Sub-section 2.2 focuses on the relationship between SCI and performance. A first set of hypotheses addresses whether internal integration is directly related to external integration ( $\mathrm{H} 1$ and $\mathrm{H} 2$ ). The second set of hypotheses covers the relationship between customer and supplier integration and external integration orientation (H3 and H4). The third set analyses whether SCI dimensions are directly related to performance (H5 and H8). The fourth set examines whether external integration orientation acts as a mediator in the relationship between customer/supplier integration and performance (H9 and H10) and whether external integration acts as a mediator in the relationship between internal integration and performance (H10 and H11). Sub-section 2.3 focuses on the relationships between EC, SCI and performance. A fifth set of hypotheses addresses the question whether EC is directly related to performance (H12). The sixth set covers the relationships between EC and SCI dimensions (H13, H14, H15). Finally, the seventh set analyses the mediated effect of internal integration and SCI (H16 to H18). Subsection 2.4 describes the objective of the paper and the proposed model.

\subsection{Theories supporting the research}

In this paper our primary theoretical focus is on the theoretical framework of the Value Chain (Porter, 1986) and the resource-based view (RBV) of the firm (Peteraf, 1993; Barney, 1991). These are two of the most commonly identified theories in SCM (Defee et al., 2010) and workforce management research. 
Porter (1986) demonstrated that competitive advantage does not come about only with the efficiency with which any individual company is managed, but with that of the value chain as a whole. As such, the value that a company achieves will depend to a great extent on the relationships it has with its customers and suppliers (Porter, 1986), i.e., the degree of SCI. SCI is directly involved in the value-adding processes required to achieve efficient and effective upstream and downstream flows of products, services, decisions, and information (Bowersox et al., 2000; Mentzer et al., 2001). An analysis of a company's SC enables its capabilities to be identified by determining the activities in which it has, or can have, a competitive advantage, and the relationships that exist among them. The company can then identify the activities it prefers to carry out itself and those that would be better acquired externally. Therefore, the organisation has to take a series of strategic decisions based on the analysis of these business capabilities that will affect SCM and SCI directly. SCI enables a company to excel at specific value-added activities for which it possesses unique advantages while relying on SC partners to provide the complementary capabilities it lacks (Dyer \& Singh, 1998).

The resource-based view (RBV) considers firms as collections of resources, some of which can be considered strategic resources (Wernerfelt, 1984). The RBV argues that firms are able to generate sustained competitive advantage by developing unique firm resources and capabilities (Barney, 1991; Peteraf, 1993). Previous research has recognised the relevancy of the RBV focus for SCM/SCI (Olavarrieta \& Ellinger, 1997; Leuschner et al., 2013) and for workforce management (Schroeder et al., 2002; Samad, 2013).

Best-value supply chains reflect the assumption that unique resources exist at the SC level, and that supply chains can be inimitable competitive weapons (Ketchen \& Hult, 2007). SCM seeks improved performance through the effective use of resources and capabilities via the development of internal and external linkages in order to create a seamlessly coordinated SC, thus elevating inter-firm competition to inter-supply chain competition (Barratt \& Barratt, 2011). SCI can be seen as a strategic resource that could result in a competitive advantage and improved firm performance (Barney, 2012). Fine (1998) considers SCI as the ultimate core capability. SCI involves restructuring activities used to link and simplify processes to help firms allocate, align, and utilise both internal and external resources (Chen et al., 2009). INTI and EI can be complex and require unique capabilities that may be difficult or costly to implement (Barney, 2012). Therefore, the relevancy of RBV to SCI becomes evident because of the engagement of both internal and external resources (Chen et al., 2009).Meanwhile, the workforce can emerge as a key element for achieving competitive advantage in the SC from the point-of-view of the RBV (Marin-Garcia et al., 2009; deSarbo et al, 2007; Schroeder et al., 2002).

Theory suggests that trust-based relationships, common goals, and system-based rewards are necessary conditions for successful firms in the SC (Menon, 2012). Appropriate workforce practices and a high degree of EC that help these objectives to be accomplished could be responsible for developing specialised forms of human capital that can be difficult to imitate and enable a sustained competitive advantage to be achieved. According to Becker \& Huselid (1998), this human capital will result in improved productivity and profitability. Consequently, EC could play a major role in achieving a sustained competitive advantage in the context of an integrated SC.

\subsection{Supply chain integration and performance}

SCI has been a highly researched topic during the last 20 years (Leuschner et al., 2013), but no consensus has been achieved on how to measure SCI and operationalisation (Alfalla-Luque et al., 2013a; Kim, 2013). Some authors examined SCI as a single construct (Vickery et al., 2003; Sezen, 2008). However, SCI multidimensional constructs have been developed due to the complex nature of the concept (Gimenez \& Ventura, 2005; Kim, 2009). The most common approach used focuses on inter- and intra-company integration (Flynn et al., 2010; Drogue et al., 2012; Zhao et al., 2013). An internal-external perspective is essential for understanding the phenomenon (Chen et al., 2009). The key to SCI is to develop uninterrupted links with upstream suppliers and downstream customers along with total internal functional synergy (Flynn et al., 2010). INTI links internally performed work into a seamless process to support customer requirements (Bowersox et al., 2003; Chen et al., 2009). It is a process of interdepartmental interaction and collaboration that brings departments together into a cohesive organisation (Kahn \& Mentzer, 1996). It implies integration between functions or departments within a single firm (Koufteros el al., 2010). EI should be achieved with supplier and customer. SI implies working in close cooperation with key suppliers in order to generate advantages, such as a reduction in inventory or a decrease in supplier lead time (Thun, 2010). CI deals with a better understanding of key customers' needs and with their considerations in the company's business processes (Thun, 2010). SCI includes both upstream and downstream players, while INTI provides the 
foundation for both (Chen et al., 2009). In consequence, every SC could have a different level of INTI, CI and SI (Frohlich \& Westbrook, 2001).

Several papers, including this research, analyse SCI using the triple SCI scope - INTI, SI, CI- (Swink et al., 2007; Wong \& Boon-itt, 2008; Kim, 2009; Flynn et al., 2010). The literature suggests that firms must achieve a relatively high degree of collaboration between internal processes before initiating EI (Fawcett \& Magnan, 2002; Harrison \& Van Hoek, 2005; Cagliano et al., 2006). One of the major obstacles to fully integrated materials and information flows across the SC seems to be the inadequacy of the individual firms' internal management systems (Mentzer, 2004). Coordination between functions is a key factor for achieving intra-organisational integration, (Fawcett \& Magnan, 2002). INTI is a prerequisite for EI with supplier and customer (Vickery et al., 2003; Menon, 2012) and must be well-established before companies integrate with external parties (Handfield \& Nichols, 2002). Successful SCM presumes INTI and EI to be in place, but neither is sufficient in itself for having a successful SC (Min, 2001). The lack of INTI becomes the biggest obstacle to turning collaborative activities into operational efficiency (Baihaqi \& Sohal, 2013). INTI has the potential to affect EI (Kim, 2013; Germain \& Iyer, 2006). A significant positive correlation between INTI and EI has been reported in previous research (Gimenez \& Ventura, 2005; Eng, 2006; Baihaqi \& Sohal, 2013). However, there is a need for more research in this area to ascertain how INTI interacts with other types of integration (Zhao et al., 2011; Kim, 2013; Alfalla-Luque et al., 2013a). The following hypotheses have been proposed in the quest to provide empirical evidence for these relationships:

\section{H1: INTI is directly and positively related to SI \\ H2: INTI is directly and positively related to CI}

The SCI focus frequently fails to consider its strategic nature (Flynn et al., 2010). Firms need to view organisations as part of a collaborative network (Menon, 2012) and to strategically collaborate with their SC partners to achieve effective SCI (Flynn et al., 2010). Partners should work together to jointly achieve greater success (efficiencies, flexibility, and sustainable competitive advantage) than can be attained in isolation (Nyaga et al., 2010). Partnership management has been classified as a form of core competency leading to competitive advantage (Miller \& Shamsie, 1996). Bearing this in mind, apart from the analysis of INTI, SI and CI, our research also considers a strategy perspective, the external integration orientation (EIO), which implies that the firm believes in a collaborative orientation towards key suppliers and customers (and not an adversarial relationship with them) as a part of its company strategy. While strategy is different from operations, integration between the two is critical (Porter, 1986; Miles \& Snow, 1978). While operational collaboration can only lead to shop-floor benefits, strategic collaboration should not only afford shop-floor benefits, but also strategic benefits (Sanders, 2008). Strategic collaboration with supplier and customer is considered to be one of the core capabilities that companies need to remain viable in the current business environment (Bowersox et al., 2000). Strategic collaborative relationships are expected to provide greater benefits than transaction-oriented relationships (Whipple et al., 2010). Taking into account previous research, we will analyse whether SI and CI are positively associated with EIO. We propose the following hypotheses:

\section{H3: SI is directly and positively related to EIO}

H4: CI is directly and positively related to EIO

A wide range of different studies on SCI have been carried out, many of them focusing on the relationship between SCI and performance (e.g., Sezen, 2008; Kim, 2009; Thun, 2010; Zhao et al., 2013). In general terms, some papers agree that the higher the level of integration, the greater the potential benefits (Frohlich \& Westbrook, 2001; Bagchi et al., 2005; Li et al., 2009). Other studies have not always found a clear relationship between the level of SCI and performance improvement (Hertz, 2001; Swink et al., 2007). Therefore, results are not conclusive (Jin et al., 2013). Detailed tables summarising the relationships between SCI and performance in previous research can be found in, among others, Table VII in Fabbe-Costes \& Jahre (2008), Table 3 in Van der Vaart \& Van Donk (2008), Table 1 in Sofyalıoğlu \& Öztürk (2012), Table I in Jin et al. (2013) and Table 1 and Table 2 in Kim (2013).

Two recent meta-analyses of SCI and performance have been carried out by Leuschner et al. (2013) and Sofyalığlu \& Öztürk, (2012) based on a sample of peer-reviewed journal articles (86 and 22, respectively). Both studies have tested the hypothesis "SCI is positively related to firm performance" taking into account four scopes of SCI (SI, CI, EI and INTI) and different measures of performance. Table 1 summarises the results. The comparison of both meta-analyses confirms the lack of consensus in prior empirical research on how SCI affects performance. There is, therefore, no consistency in the findings on the relationship between 
SCI and performance. Perhaps the lack of consensus could be attributed to the different SCI definitions, dimensions and operationalisations used in each of the studies and their different scopes (Van der Vaart \& Van Donk, 2008; Alfalla-Luque et al., 2013a; Jin et al., 2013). For example, studies that aggregate SI and CI in a single construct (EI) may be drawing inaccurate conclusions (Flynn et al., 2010). The same may be true when we analyse the performance measures grouped into a single construct. In the same way, the performance measures tested are very wide and also apply at different levels of analysis: team, project, plant, and SC (Turkulainen \& Ketokivi, 2012). Another reason could be that SCI does not have the same impact on performance depending on the country, industry, plant age, product complexity and plant size (Flynn et al., 2010). For example, in some contexts it might be better to negotiate for each purchase than have partnerships (in line with Transaction Cost Economics). However, SCI is a key element for improvement in sectors such as the car industry (Gimenez \& Ventura, 2003). In other words, as with RBV, SCI achieves sustainable competitive advantages and improved performance if partners possess unique complementary capabilities that can produce distinctive value and the governance skills needed for effective integration (Jin et al., 2013; Fawcett et al., 2007). Another factor that could create ambiguity in the effect of SCI on performance is that the relationship could be nuanced (Jin et al., 2013). For example, some authors have found that various operational performance measures mediate the relationship between SCI and financial performance (Vickery et al., 2003; Allred et al., 2011). Other papers conclude that there are variables that act as antecedents and SCI has a mediating effect between these antecedents and performance (Vanichchinchai \& Igel, 2011; Vanichchinchai, 2012; Wu et al., 2014).

\begin{tabular}{|l|l|l|}
\hline Relationship & Leuschner et al. (2013) & Sofyalığlu \& Öztürk, (2012) \\
\hline SCI / Firm performance & Positive and significant & Non significant \\
\hline EI / Firm performance & Positive and significant & -- \\
\hline SI / Firm performance & Weak & -- \\
\hline CI / Firm performance & Non significant & -- \\
\hline INTI / Firm performance & Positive and significant & -- \\
\hline SCI / Business performance & Weak & Non significant \\
\hline CI / Business performance & -- & Non significant \\
\hline SI / Business performance & -- & Non significant \\
\hline INTI / Business performance & -- & Positive and significant \\
\hline SCI / Financial performance & Non significant & -- \\
\hline SCI / Customer-oriented & Positive and significant & -- \\
\hline SCI / Relational performance & Positive and significant & -- \\
\hline SCI / Operational performance & Positive and significant & Non significant \\
\hline CI / Operational performance & -- & Positive and significant \\
\hline SI / Operational performance & -- & Non significant \\
\hline INTI / Operational performance & -- & Non significant \\
\hline SCI / Delivery & Positive and significant & -- \\
\hline SCI / Quality & Positive and significant & -- \\
\hline SCI / Innovation & Positive and significant & -- \\
\hline SCI / Cost & Non significant & -- \\
\hline SCI / Flexibility & Non significant & -- \\
\hline
\end{tabular}

Table 1. Comparison between meta-analyses of SCI and performance

Sofyalığlu \& Öztürk (2012) state that there are few studies in the literature that test the direct relationship between SCI and performance, so they suggest more studies to test this relationship. Leuschner et al. (2013) state the need for additional research to make statements generalisable. We analyse this relationship in response to this demand. Although there is no consensus, we propose the following hypotheses in a positive sense ${ }^{4}$ :

H5: INTI is directly and positively related to performance

H6: SI is directly and positively related to performance

H7: $\mathrm{CI}$ is directly and positively related to performance

H8: EIO is directly and positively related to performance

${ }^{4}$ All the performance-related hypotheses analyse each measure separately. 
Also, taking into account the possible existence of mediated variables (Jin et al., 2013), we analyse, firstly, whether the existence of EIO in a firm could act as a mediating variable between either SI or CI and performance. We therefore propose the following hypotheses:

H9: EIO acts as a mediator in the relationship between SI and performance

H10: EIO acts as a mediator in the relationship between CI and performance

Secondly, as already indicated, there are many prior studies that state that having INTI is a prerequisite for attaining adequate EI (Eng, 2006; Menon, 2012; Kim, 2013; Baihaqi \& Sohal, 2013). For this reason we propose to analyse INTI empirically as an antecedent of EI, examining the mediating effect of EI (analysed through the block formed of the SI/CI/EIO constructs) in the INTI-performance relationship, with the following hypothesis:

\section{H11: The SI/CI/EIO block acts as a mediator in the relationship between INTI and performance}

\subsection{Employee commitment, supply chain integration and performance}

EC is defined as the degree to which a worker identifies with his/her firm and shares its goals and values (Fields, 2002; Meyer et al., 1993; Mowday \& Steers, 1979). Employees with high commitment consider that their company is an organisation for which it is worth working and which they are proud of working for (Alfalla-Luque et al., 2012). As a result, they put all their efforts into working well for the organisation, do so with greater autonomy, develop core competencies more quickly and, moreover, tend to be more accepting of any task given to them. The likelihood that the firm will achieve better performance therefore rises (Kuo, 2013).

There is clear evidence of the mediating role of EC between workforce management practices and firm performance in previous research in the area of human resources (Elorza et al., 2011; Patterson et al., 2010). In other words, when the effects of workforce management practices on performance are analysed without including EC in the model, these effects are significant and positive. However, when the mediating variable is included, the direct relationship between workforce management practices and performance disappears, and only the relationship between workforce management and EC and the relationship between EC and performance remain significant.

Recent models in the literature on workforce management (Den Hartog et al., 2004; Elorza et al., 2011; Guest \& Conway, 2011; Marin-Garcia, 2013) consider EC as the main mediating construct for explaining operational performance and customer satisfaction, both of which affect financial performance (Table 2).

\begin{tabular}{|l|l|}
\hline \multicolumn{1}{|c|}{ Relationship } & \multicolumn{1}{|c|}{ Direct,positive and significant } \\
\hline EC / Cost & $\begin{array}{l}\text { Guest (2001); Paul \& Anantharaman (2003); Young \& Choi (2011); } \\
\text { Vanichchinchai (2012) }\end{array}$ \\
\hline EC / Delivery & Paul \& Anantharaman (2003) \\
\hline EC / Flexibility & Vanichchinchai (2012) \\
\hline EC / Productivity & $\begin{array}{l}\text { Guest (2001); Samad (2013); Boselie et al. (2005); Paul \& Anantharaman (2003); } \\
\text { Young \& Choi (2011); Brown et al. (2011) }\end{array}$ \\
\hline EC / Quality & $\begin{array}{l}\text { Guest (2001); Boselie et al. (2005); Paul \& Anantharaman (2003); Young \& Choi } \\
\text { (2011); Katou (2011) }\end{array}$ \\
\hline EC / Innovation and development & Katou (2011); Young \& Choi (2011) \\
\hline EC / Customer satisfaction & Moynihan et al. (2001); Kuo (2013); Nishii et al. (2008) \\
\hline EC / Financialperformance & Brown et al. (2011); Samad (2013) \\
\hline Relationship & \multicolumn{1}{|c|}{ Mediated by } \\
\hline EC / Financial performance & $\begin{array}{l}\text { Productivity and quality: Boselie et al. (2005) } \\
\text { Employee retention, employee productivity, product quality, speed of delivery, } \\
\text { operating cost: Paul \& Anantharaman (2003) } \\
\text { New product development, efficiency of task procedures, cost reduction, product } \\
\text { quality, and overall productivity and defect reduction: Young \& Choi (2011) } \\
\text { Productivity and quality: Guest (2001) }\end{array}$ \\
\hline
\end{tabular}

Table 2. Relationship between EC and performance in previous research

Table 2 synthesises the relationships identified in the prior literature. The majority of these studies analyse performance measures grouped into operational and financial performance. This paper has analysed each of the performance measures (flexibility, delivery, quality, inventory and customer satisfaction) separately with the aim of providing more detailed empirical evidence. Therefore, we propose that: 


\section{H12: EC is directly and positively related to performance}

Previous literature shows that workforce management is one of the less studied topics in SCM/SCI (Giunipero et al., 2008; Pandey et al., 2012; Fisher et al., 2010). This lack of research may perhaps be due to the research emphasis being put on hard OM topics, such as JIT, TQM or IT, so more empirical testing needs to be done (Shub \& Stonebraker, 2009). While the relationship between SCI and performance has been widely analysed in the literature, we find a lack of research with respect to any possible antecedents of this relationship (Jin et al., 2013). In other respects, the relationship between workforce management, EC and performance has also been studied widely in previous research. However, there are few studies that extend the model and connect the two lines of research. Consequently, this paper seeks to make a contribution to this line by studying EC as a possible antecedent of SCI.

Opportunities for competitive advantage increasingly lie in managing people within and between firms in SC relationships (Ketchen \& Hult, 2007; Fawcett et al., 2008; Fisher et al., 2010; Pandey et al., 2012). In this regard, Mentzer et al. (2001) identify commitment as one of the antecedents of SCM and Gundlach et al. (1995) and Lambert et al. (1998) state that it is an important ingredient for the successful implementation of SCM.

In the SCM literature the studies that address workforce management usually focus on the influence that human resources have on the relationships between the organisations that it comprises. Vanichchinchai (2012) states that most SCM frameworks, such as the SCM frameworks proposed by the Global Supply Chain Forum (GSCF), include business partner issues but almost totally ignore the internal employee component. However, the successful implementation of SCM requires integrating internal functions of the firm and effectively linking them with the external operations of its partner firms in the SC (Holmberg, 2000). When commitment is encouraged within an individual firm it will lead that firm to act cooperatively with other firms in implementing SCM (Mello \& Stank, 2005). Therefore, EC issues within the organisation should be critical in achieving SCM excellence (Halldorsson et al., 2008; Gowen III \& Tallon, 2003; Shub \& Stonebraker, 2009). Despite this, the influence of an organisation's EC on achieving SCI is a little studied topic (Bayo-Moriones \& Merino-Díaz, 2004). We formulate the following hypotheses in order to provide empirical evidence on the topic:

H13: EC is directly and positively related to INTI

H14: EC is directly and positively related to SI

H15: EC is directly and positively related to CI

In other respects, as far as we know, only a few studies analyse the relationships between EC, SCM/SCI and performance (Gowen III \& Tallon, 2003; Vanichchinchai \& Igel, 2011; Vanichchinchai, 2012). The conclusion of Vanichchinchai \& Igel (2011) is that the SCM practices mediate the effect of TQM on company performance, and the explanation for this result is that the EC on which TQM focuses is a critical foundation for SCM, as it facilitates INTI. Gowen III \& Tallon (2003) concludes that EC is crucial for SCM practices to succeed. EC makes a critical independent contribution to the success of all of the SC practices. They also conclude that EC mediates the adverse impact of SCM implementation barriers on SCM success. Vanichchinchai (2012) found that employee involvement does not only have a direct positive impact on relationships with suppliers and customers (EI) and performance, but also an indirect positive impact on performance through EI. Thus, he found a mediating effect of EI in the relationship between employee involvement and performance.

In conclusion, the few prior studies that exist seem to identify a possible mediating effect of SCI in the relationship between EC and performance, as has been demonstrated in other OM practices (e.g., TQM, JIT and TPM). As they analyse both SCI and performance aggregated into a single construct they do not examine the relationships between the SCI dimensions or with regard to the various performance measures. In this study we have analysed the SCI dimensions and the performance measures in disaggregation in order to provide more detailed empirical evidence and thus respond to the demand for greater research into EC as a possible antecedent of SCI and performance identified in the literature. The following hypotheses have been proposed in order to contribute to progress in this line:

H16: INTI acts as a mediator in the relationship between EC and SI

H17: INTI acts as a mediator in the relationship between EC and CI

H18: SCI acts as a mediator in the relationship between EC and performance 


\subsection{Objectives and proposed model}

The general objective of this research is to analyse the relationships between EC (as an antecedent) and SCI to explain several performance measures. However, in the proposed model (Figure 2) we have established hypotheses focusing not only on the mediation relationships, but also on the direct relationships between variables that need more research taking into account the previous literature. We have therefore analysed the direct relationships between: (1) The different dimensions of SCI, paying particular attention to INTI, traditionally underestimated in previous studies (H1 to H4); (2) SCI dimensions and performance (H5 to H8); (4) EC and performance (H12); (3) EC and SCI dimensions (H13 to H15). We have also analysed the mediation relationships of: (5) EI between INTI and performance (H9 to H11); (6) SCI dimensions between EC and performance (H16 to H18).

Five performance measures have been analysed separately: flexibility, delivery, quality, inventory and customer satisfaction. The results have therefore been obtained individually for each performance measure. This paper contributes to the prior literature by providing empirical evidence in the six analysis groups (direct and indirect) by analysing the effects on the five performance measures separately (in H5 to H12 and H18).

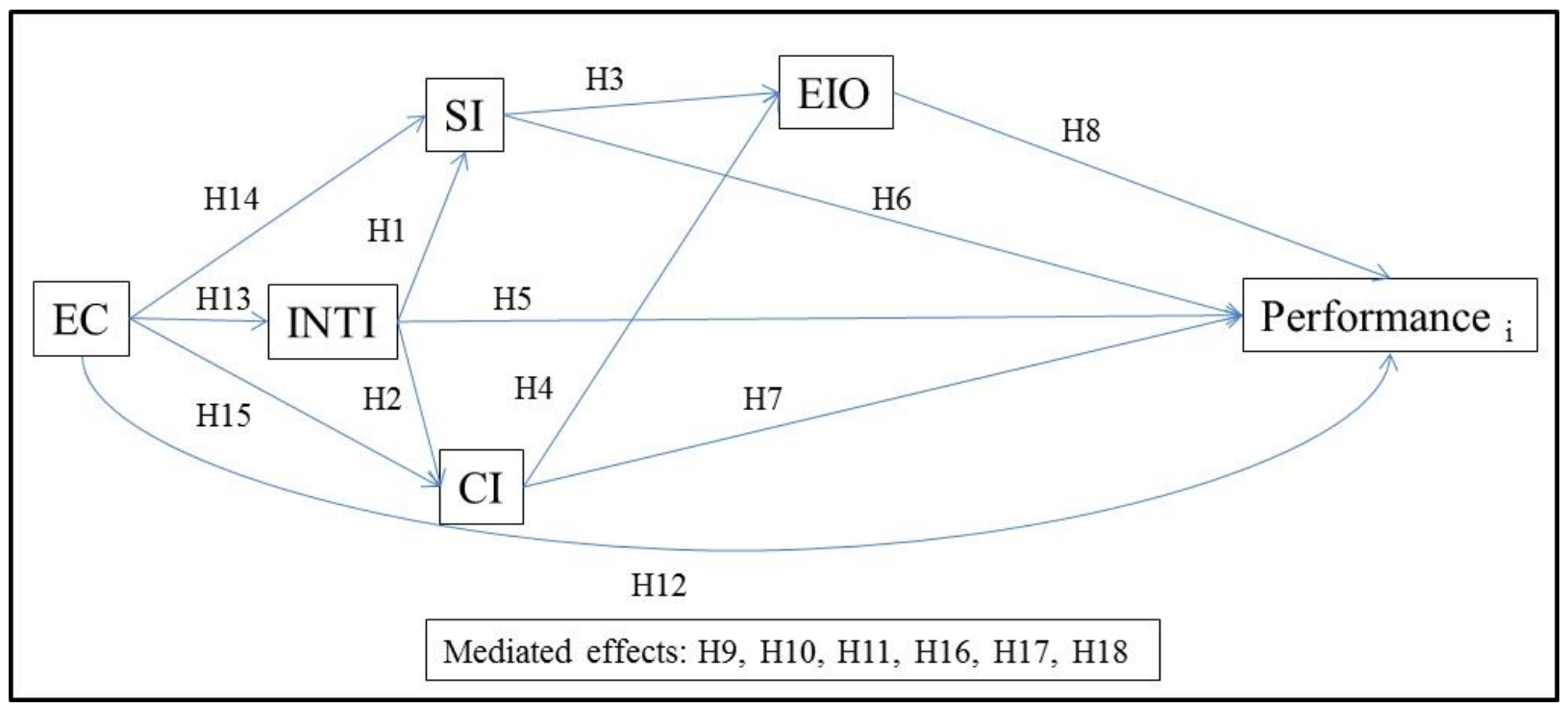

Figure 2. Proposed model and hypotheses

\section{Methodology}

\subsection{Sample}

Our empirical analysis is based on the HPM project database, the data for which was collected during the project's third round in 266 mid-to-large-sized manufacturing plants (more than 100 employees) in three industries in 2005-2008 in nine countries (Table 3). The unit of observation is the manufacturing plant. A stratified sampling design (Forza, 2002) was used to obtain an approximately equal number of plants for each industry-country combination. All plants within a given country were from different parent corporations. The average response rate was approximately 65\%. Given the sample's characteristics, this research is framed in a manufacturing context. 


\begin{tabular}{|l|c|c|c|c|}
\hline Countries & $\begin{array}{c}\text { Automotive } \\
\text { components }\end{array}$ & Electronics & Machinery & Total \\
\hline Austria & 4 & 10 & 7 & $\mathbf{2 1}$ \\
\hline Finland & 10 & 14 & 6 & $\mathbf{3 0}$ \\
\hline Germany & 19 & 9 & 13 & $\mathbf{4 1}$ \\
\hline Italy & 7 & 10 & 10 & $\mathbf{2 7}$ \\
\hline Japan & 13 & 10 & 12 & $\mathbf{3 5}$ \\
\hline Korea & 11 & 10 & 10 & $\mathbf{3 1}$ \\
\hline Spain & 10 & 9 & 9 & $\mathbf{2 8}$ \\
\hline Sweden & 7 & 7 & 10 & $\mathbf{2 4}$ \\
\hline USA & 9 & 9 & 11 & $\mathbf{2 9}$ \\
\hline Total & $\mathbf{9 0}$ & $\mathbf{8 8}$ & $\mathbf{8 8}$ & $\mathbf{2 6 6}$ \\
\hline
\end{tabular}

\subsection{Instrument}

This research uses the HPM third round questionnaire. The original survey items were based on a wideranging review of the prior OM literature. A panel of experts reviewed the instruments in order to ensure content validity and a pilot test was conducted at several plants with pre-tests that had been analysed for reliability, validity and internal consistency. The international HPM research questionnaires were reviewed during the first and second rounds. The construction validity, internal consistency and nomological validity therefore presented strong values in the scales that were finally used (Schroeder \& Flynn, 2001; Flynn, et al., 1995).

Each questionnaire in this research was tailored to the expertise of the focal informant following the key informant method (Bagozzi et al., 1991). The items used in the present research were responded to by at least two different managers/workers (plant accounting managers, direct labour, human resource managers, inventory managers, process engineers, plant managers, quality managers, supervisors) in the plant for information to be triangulated. This gives a transversal image of a plant so that key informant bias can be avoided (Van Bruggen et al., 2002) while simultaneously increasing the validity.

\subsection{Operationalisation}

The items concerning EC, INTI, CI, SI, EOI and customer satisfaction are measured on a 1-7 Likert scale asking informants for their perception $(1=$ strongly disagree, $4=$ neither agree nor disagree, $7=$ strongly agree). The items concerning operational performance (delivery, flexibility, inventory and quality) are measured on a 1-5 Likert scale asking key informants for their perception of past performance compared to competitors $(1=$ Poor, low end of industry, 5 = superior $)$. Table 4 shows the items of each construct. For each item, plant-level data are calculated as an average value of all the valid responses at the company. All the constructs used are first-order constructs. 


\begin{tabular}{|c|c|c|c|}
\hline Constructs & Description & \begin{tabular}{|c|}
$\begin{array}{c}\text { Standardised } \\
\text { loads }\end{array}$ \\
\end{tabular} & $\begin{array}{c}\text { Convergent } \\
\text { validity* }\end{array}$ \\
\hline \multirow{3}{*}{$\begin{array}{l}\text { Customer } \\
\text { Integration } \\
\text { (CI) }\end{array}$} & We frequently are in close contact with our customers. & \begin{tabular}{|l|}
0.745 \\
\end{tabular} & \multirow{3}{*}{$\begin{array}{c}\alpha: 0.77 \\
\text { CR:0.80 } \\
\text { EV:0.58 }\end{array}$} \\
\hline & $\begin{array}{l}\text { Our customers give us feedback on our quality and delivery } \\
\text { performance. }\end{array}$ & 0.822 & \\
\hline & We strive to be highly responsive to our customers' needs. & 0.711 & \\
\hline \multirow{3}{*}{$\begin{array}{l}\text { External } \\
\text { Integration } \\
\text { Orientation } \\
(\mathrm{EOI})\end{array}$} & $\begin{array}{l}\text { We work as a partner with our suppliers, rather than having an } \\
\text { adversarial relationship. }\end{array}$ & 0.734 & \multirow{3}{*}{$\begin{array}{c}\alpha: 0.72 \\
\text { CR:0.71 } \\
\text { EV:0.45 }\end{array}$} \\
\hline & $\begin{array}{l}\text { We believe that cooperative relationships will lead to better } \\
\text { performance than adversarial relationships. }\end{array}$ & 0.619 & \\
\hline & $\begin{array}{l}\text { We believe than an organisation should work as a partner with its } \\
\text { surrounding community. }\end{array}$ & 0.654 & \\
\hline \multirow{3}{*}{$\begin{array}{l}\text { Supplier } \\
\text { Integration } \\
\text { (SI) }\end{array}$} & $\begin{array}{l}\text { We maintain close communication with suppliers about quality } \\
\text { considerations and design changes. }\end{array}$ & 0.857 & \multirow{3}{*}{$\begin{array}{c}\alpha: 0.74 \\
\text { CR:0.77 } \\
\text { EV:0.53 }\end{array}$} \\
\hline & We maintain cooperative relationships with our suppliers. & 0.656 & \\
\hline & We strive to establish long-term relationships with suppliers. & 0.643 & \\
\hline \multirow{3}{*}{$\begin{array}{l}\text { Internal } \\
\text { Integration } \\
\text { (INTI) }\end{array}$} & Departments in the plant communicate frequently with each other. & 0.730 & \multirow{3}{*}{$\begin{array}{c}\alpha: 0.79 \\
\text { CR:0.79 } \\
\text { EV:0.55 }\end{array}$} \\
\hline & Management works together well on all important decisions & 0.745 & \\
\hline & Generally speaking, everyone in the plant works well together. & 0.755 & \\
\hline \multirow{3}{*}{$\begin{array}{l}\text { Employee } \\
\text { Commitment } \\
\text { (EC) }\end{array}$} & $\begin{array}{l}\text { I talk up this organisation to my friends as a great organisation to } \\
\text { work for. }\end{array}$ & 0.861 & \multirow{3}{*}{$\begin{array}{c}\alpha: 0.89 \\
\text { CR:0.90 } \\
\text { EV:0.75 }\end{array}$} \\
\hline & I am proud to tell others that I am part of this organisation. & 0.901 & \\
\hline & $\begin{array}{l}\text { I am extremely glad that I chose this organisation to work for, over } \\
\text { others I was considering at the time I joined. }\end{array}$ & 0.840 & \\
\hline \multirow{2}{*}{$\begin{array}{l}\text { Delivery } \\
\text { (Del) }\end{array}$} & On time delivery performance & 0.812 & \multirow{2}{*}{$\begin{array}{c}\alpha: 0.77 \\
\text { CR: } 0.77 \\
\text { EV:0.63 }\end{array}$} \\
\hline & Fast delivery & 0.767 & \\
\hline \multirow{2}{*}{$\begin{array}{l}\text { Flexibility } \\
\text { (Flex) }\end{array}$} & Flexibility to change product mix & 0.664 & \multirow{2}{*}{$\begin{array}{c}\alpha: 0.70 \\
\text { CR:0.72 } \\
\text { EV0.56 }\end{array}$} \\
\hline & Flexibility to change volume & 0.828 & \\
\hline \multirow{2}{*}{$\begin{array}{l}\text { Inventory } \\
\text { (Inv) }\end{array}$} & Inventory turnover & 0.647 & \multirow{2}{*}{$\begin{array}{c}\alpha: 0.73 \\
\text { CR:0.74 } \\
\text { EV:0.60 }\end{array}$} \\
\hline & Cycle time (from raw materials to delivery) & 0.881 & \\
\hline \multirow{2}{*}{$\begin{array}{l}\text { Quality } \\
\text { (Q) }\end{array}$} & Conformance to product specifications & 0.681 & \multirow{2}{*}{$\begin{array}{c}\alpha: 0.62 \\
\text { CR:0.59 } \\
\text { EV:0.42 }\end{array}$} \\
\hline & Product capability and performance & 0.611 & \\
\hline \multirow{4}{*}{$\begin{array}{l}\text { Customer } \\
\text { satisfaction } \\
\text { (CS) }\end{array}$} & $\begin{array}{l}\text { Our customers are pleased with the products and services we } \\
\text { provide for them. }\end{array}$ & 0.880 & \multirow{4}{*}{$\begin{array}{c}\alpha: 0.88 \\
\text { CR:0.88 } \\
\text { EV:0.65 }\end{array}$} \\
\hline & $\begin{array}{l}\text { Our customers seem happy with our responsiveness to their } \\
\text { problems. }\end{array}$ & 0.729 & \\
\hline & \begin{tabular}{|l|} 
Customer standards are always met by our plant. \\
\end{tabular} & 0.735 & \\
\hline & $\begin{array}{l}\text { Our customers have been well satisfied with the quality of our } \\
\text { products, over the past three years. }\end{array}$ & 0.862 & \\
\hline
\end{tabular}

* $\alpha$ (Cronbach's Alpha), CR (compound reliability), EV (Extracted Variance)

Table 4. Construct items

\subsection{Method of analysis}

The HPM project data constitute a broad sample, which enables the Structural Equation Model (SEM) to be used (Marin-Garcia et al., 2013). The analyses have been done with the EQS programme using the maximum verisimilitude parameter estimation method (Bentler, 2002). Goodness of fit will be evaluated with a robust method to prevent departures from multivariate normality in the data. The two-step modelling approach (Schumacker \& Lomax, 1996) will be used to check the measurement model and the full latent structural model. In all cases, an analysis will be carried out on the psychometric properties of the construct measurement models. This will verify each construct's goodness of fit, the significance of the load on each of the items and that their standardised values are greater than 0.6. Composite reliability and Cronbach's Alpha will also be tested to ensure that they are over 0.7 and that the variance extracted is over 0.4 (Hair et al., 1995). Discriminant validity will be tested using the confidence interval for correlations method (Anderson \& Gerbing, 1988).

Apart from analysing direct relationships between constructs, this paper also analyses possible mediating 
relationships. Mediation is one of several different relationships that can occur when a third construct $\mathrm{Z}$ (called the mediator) is included in the analysis between two other constructs (X-->Y, where $X$ is the independent construct and $\mathrm{Y}$ the dependent construct) in such a way that $\mathrm{X}$ is the cause of $\mathrm{Z}$ which, in turn, is the cause of Y. Mediation can be full or partial. In the case of full mediation the direct effect between $X$ and $\mathrm{Y}$ is no longer significant when the mediating variable $(\mathrm{Z})$ is introduced. In partial mediation the direct effect diminishes but does not disappear altogether and a direct effect $(\mathrm{X}-->\mathrm{Y})$ and an indirect effect $(\mathrm{X}-->\mathrm{Z}-->\mathrm{Y})$ exist alongside each other with the full effect being the sum of the direct and indirect effects. An alternative situation to mediation may also occur: suppression. In suppression the direct and indirect effects have opposite arithmetic signs (Alto \& Vallejo, 2011).

Three steps must be taken to test whether a construct acts as a mediator between other constructs. The standardised loads and their significance must be calculated separately in each of these three steps (Baron \& Kenny, 1986). The first step is to analyse the relationship between $X$ and $Z$. During the second step, the relationship between $\mathrm{X}$ and $\mathrm{Y}$ is analysed. Lastly, $\mathrm{X}, \mathrm{Y}$ and $\mathrm{Z}$ are included in the model. For a mediating relationship to exist, the following conditions must all be met simultaneously: a) in step $1, X$ must have a significant load in the direct path on Z; b) in step 2, X must have direct effect on Y; c) in step 3, Z must have a significant load in the direct path on Y; d) X's direct load on Y should be lower in step 3 than in step 2. In short, testing mediation implies the prior analysis of the direct relationships between the constructs, whereby all our hypotheses for both mediation and direct relationships will be based on the significance of the paths of the analyses undertaken in these three steps.

We seek to verify several mediating blocks in our research. The three steps proposed by Baron \& Kenny (1986) have been followed for each of these three proposed mediating blocks. For this we have established different models (Figure 3). (1) The first block verifies the possible mediation of EIO in the relationship between SI or CI and the performance measures (H9 and H10). For this analysis we shall use models 1, 2 and 3. Versions of model 2 and 3 were constructed and analysed separately for each of the five performance constructs in order to prevent pivoting problems in the SEM parameter estimation process. These models enable the parameters required for testing hypotheses H3, H4, H6, H7 and H8 to be estimated. (2) The second block, studies the possible joint mediation of all the EI dimensions in block 1 (SI/CI/EIO) between INTI and the performance measures (H11). The use of models 1,3 and 4 is proposed for this and these same models provide the data for testing hypotheses H1, H2, H5. (3) The third block tests whether INTI mediates in the relationship between EC and CI and SI (H16 and H17). For this we propose models 1, 5 and 7, which also enable hypotheses H13, H14 and H15 to be tested. (4) The fourth and last block enables us to test whether SCI (sequence established in blocks 1, 2 and 3) acts as a mediator between EC and the performance measures (H18). Models 4, 5 and 6 are used for this fourth block and the results can be used to assess hypothesis $\mathrm{H} 12$.

Models 4, 5 and 6 in Figure 3 include all the performance variables simultaneously, but not integrated in a single construct. Model 5 is a generalisation of model 3, but only includes the direct paths between CI, SI and EOI and the performance measures that are significant or do not cause a net suppression effect. 


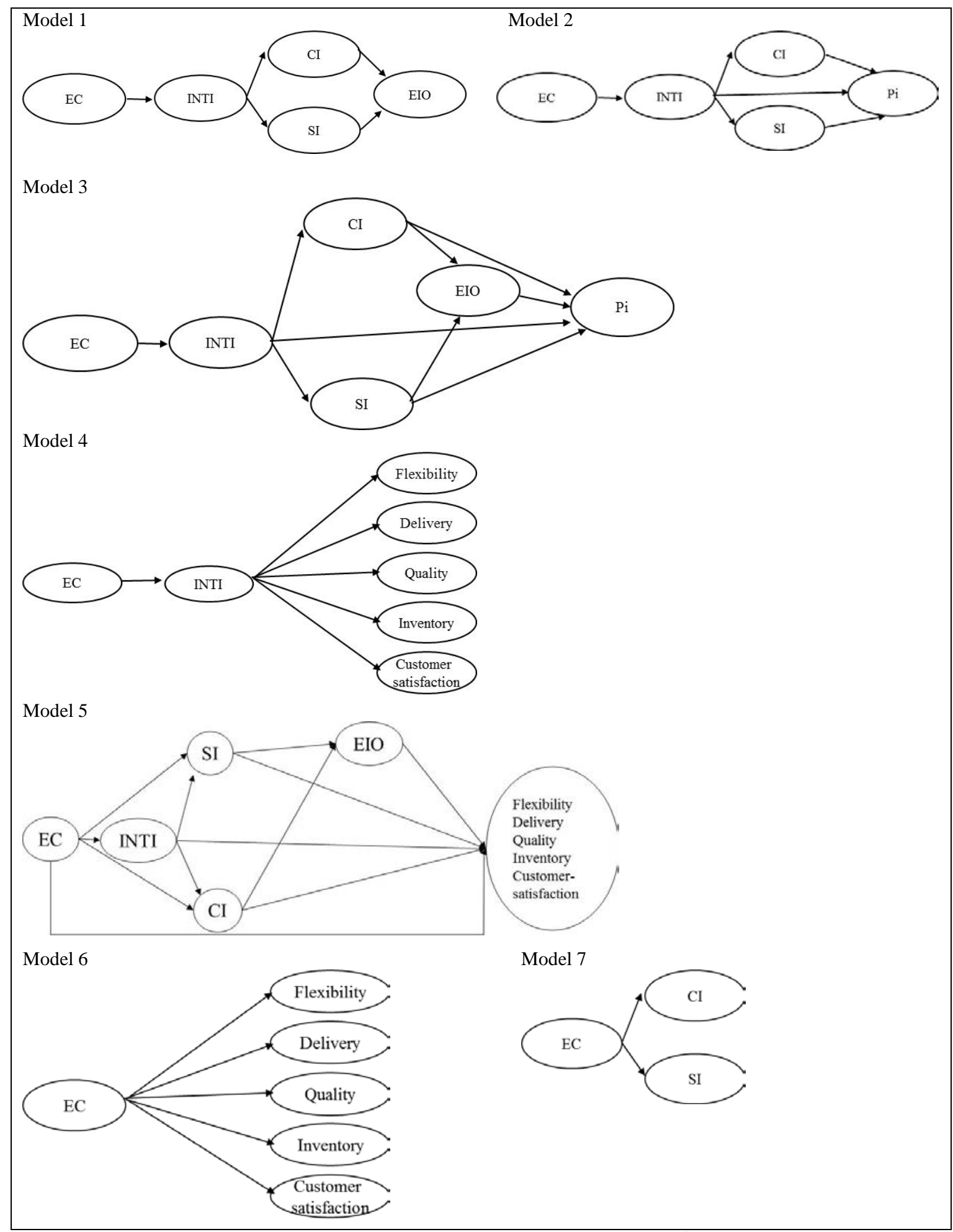

Figure 3. Models for analysis ${ }^{5}$

\section{Results}

Table 5 summarises the descriptive statistics of the constructs analysed. All of the correlations are positive, and most are significant and of moderate or low intensity. The high correlation between CI and customer satisfaction stands out while, at the other extreme, so does the absence of significant correlation between CI and inventory and quality, or between SI and flexibility and inventory. There is moderate to low correlation between the performance variables (except in the case of inventory and customer satisfaction, which is not

${ }^{5}$ The measurement model was also included in the analyses but for greater clarity only the model's structure is shown in Figure 3. In model 5 each performance construct has its own path (similar to models 4 and 6), but we have combined several paths in a single line to make the figure clearer. 
significant).

\begin{tabular}{|c|c|c|c|c|c|c|c|c|c|c|}
\hline & CI & SI & EIO & INTI & EC & Del & Flex & Inv & $\mathbf{Q}$ & CS \\
\hline CI & & $0.539 * *$ & $0.324^{* * *}$ & $0.542^{* * *}$ & $0.377^{*} * *$ & $0.293^{* * *}$ & $0.285^{* *}$ & 0.082 & 0.100 & $0.700^{* * *}$ \\
\hline SI & & & $0.537 * *$ & $0.398^{* * *}$ & $0.363 * *$ & $0.218^{*}$ & 0.132 & 0.081 & $0.190^{*}$ & $0.541^{* * *}$ \\
\hline EIO & & & & $0.452^{* * *}$ & $0.374^{* * *}$ & $0.414^{* * *}$ & $0.340^{* * *}$ & $0.335^{* *}$ & $0.342^{* *}$ & $0.272^{* * *}$ \\
\hline INTI & & & & & $0.638 * *$ & $0.344 * *$ & $0.397 * *$ & $0.171+$ & $0.269 * *$ & $0.566^{* * *}$ \\
\hline EC & & & & & & $0.161^{*}$ & $0.348^{* *}$ & $0.173^{*}$ & $0.322 * *$ & $0.494^{* * *}$ \\
\hline Del & & & & & & & $0.613^{* *}$ & $0.451^{* * *}$ & $0.577^{*} * *$ & $0.260^{* * *}$ \\
\hline Flex & & & & & & & & $0.413 * *$ & $0.408^{* * *}$ & $0.222^{* * *}$ \\
\hline Inv & & & & & & & & & $0.473 * *$ & 0.120 \\
\hline $\mathbf{Q}$ & & & & & & & & & & $0.262 * *$ \\
\hline \multicolumn{11}{|l|}{$\mathrm{CS}$} \\
\hline Mean $^{6}$ & 5.7 & 5.5 & 5.8 & 5.3 & 5.4 & 3.8 & 3.9 & 3.4 & 3.9 & 5.3 \\
\hline Variance & 0.55 & 0.50 & 0.50 & 0.63 & 0.37 & 0.58 & 0.45 & 0.52 & 0.38 & 0.33 \\
\hline N Valid & 240 & 240 & 240 & 240 & 240 & 240 & 240 & 240 & 240 & 240 \\
\hline
\end{tabular}

Correlations in bold are significant. ( $\alpha$ significance: $+10 \%$; *5\%; ** $1 \%$ ) ${ }^{6}$.

Table 5. Descriptive statistics and correlation between constructs.

The measurement model of all the constructs has adequate goodness-of-fit indices (normed Chi-squared $<$; CFI $>0.90$; IFI >0.90; MIFI >0.90; AGFI >0.90; GFI >0.85; RMSEA $<0.08$ ). Additionally (Table 4), all the factor loadings of the items associated with the first-order constructs are significant with values of over 0.6 and the Cronbach's alpha and compound reliability are over 0.7 (except for quality). Discriminant validity has been verified as none of the correlations includes one in its $95 \%$ confidence interval.

Starting with the first block explained in the methodology section, models 1, 2 and 3 have been analysed in order to test hypotheses H3, H4 and H6 to H10. Table 6 summarises the analyses for models 2 and 3. The results of model 1 can be seen in Table 7 and Table 9. All three models show good goodness-of-fit. Additionally, all the estimated factor loadings are significant. In other respects, although the correlations between the constructs are all positive (Table 5), some of the standardised loadings are negative (Table 6). This is due to a negative net suppression effect which is produced when the effects of the explanatory constructs reduce the mediating constructs' variance of error rather than explaining variation in performance directly (Darmawan \& Keeves, 2006; Howell, 2010).

\begin{tabular}{|c|c|c|c|c|c|c|c|c|c|c|}
\hline \multirow[t]{2}{*}{$\begin{array}{l}\text { Dependent } \\
\text { construct } \rightarrow\end{array}$} & \multicolumn{2}{|c|}{ Flexibility } & \multicolumn{2}{|c|}{ Delivery } & \multicolumn{2}{|c|}{ Quality } & \multicolumn{2}{|c|}{ Inventory } & \multicolumn{2}{|c|}{$\begin{array}{c}\text { Customer } \\
\text { Satisfaction } \\
\end{array}$} \\
\hline & $\operatorname{Mod} 2$ & Mod 3 & \begin{tabular}{|l|}
$\operatorname{Mod} 2$ \\
\end{tabular} & $\operatorname{Mod} 3$ & Mod 2 & $\operatorname{Mod} 3$ & Mod 2 & Mod 3 & $\operatorname{Mod} 2$ & Mod 3 \\
\hline CI-Perf & 0.085 & 0.073 & 0.132 & 0.120 & -0.152 & -0.150 & -0.045 & -0.038 & $0.503^{* *}$ & $0.519^{* * *}$ \\
\hline SI-Perf & -0.085 & $-0.184+$ & 0.039 & -0.093 & 0.092 & -0.031 & 0.084 & -0.171 & $0.178^{* *}$ & $0.255^{* * *}$ \\
\hline EIO-Perf & --- & $0.224^{* * *}$ & --- & $0.330^{* * *}$ & --- & $0.291^{* * *}$ & --- & $0.381^{* *}$ & --- & $-0.164^{*}$ \\
\hline INTI-Perf & $0.383^{* *}$ & $0.348^{* * *}$ & $0.233^{* * *}$ & 0.179 & $0.347^{* * *}$ & $0.256^{* *}$ & 0.175 & 0.102 & $0.243^{* *}$ & $0.255^{* * *}$ \\
\hline CI-EIO & -- & $0.163+$ & --- & 0.159 & -- & $0.170^{*}$ & --- & 0.097 & -- & $0.160+$ \\
\hline \begin{tabular}{|l|} 
SI-EIO \\
\end{tabular} & $--\cdot$ & $0.449^{* * *}$ & $\begin{array}{ll}-- \\
\end{array}$ & $0.453^{* *}$ & -- & $0.456^{* *}$ & $-\cdots$ & $0.510^{* * *}$ & $-\cdots$ & $0.483^{* * *}$ \\
\hline INTI-CI & $0.582^{* *}$ & $0.589^{* * *}$ & $0.572^{* *}$ & $0.579 * *$ & $0.577^{* * *}$ & $0.585^{* *}$ & $0.574^{* * *}$ & $0.579^{* *}$ & $0.600^{* * *}$ & $0.611^{* * *}$ \\
\hline INTI-SI & $0.428 * *$ & $0.447 * *$ & $0.442^{* * *}$ & $0.438^{* * *}$ & $0.443 * *$ & $0.466^{* *}$ & $0.431^{* *}$ & $0.451^{* *}$ & $0.431 * *$ & $0.454^{* * *}$ \\
\hline EC-INTI & $0.659 * *$ & $0.659^{* * *}$ & $0.645^{* *}$ & $0.647 * *$ & $0.659 * *$ & $0.658 * *$ & $0.661^{* *}$ & $0.660^{* *}$ & $0.647^{* * *}$ & $0.648^{* * *}$ \\
\hline R2 & 0.168 & 0.192 & 0.119 & 0.195 & 0.112 & 0.135 & 0.041 & 0.115 & 0.574 & 0.598 \\
\hline Chi2 & 107.7 & 165.5 & 94.7 & 160.1 & 88.2 & 150.3 & 99.0 & 161.9 & 181.9 & 263.7 \\
\hline Df & 71 & 110 & 71 & 110 & 71 & 110 & 71 & 110 & 98 & 143 \\
\hline Sig & 0.003 & 0.001 & 0.03 & 0.001 & 0.08 & 0.006 & 0.016 & 0.000 & 0.000 & 0.000 \\
\hline GFI & 0.94 & 0.92 & 0.94 & 0.92 & 0.95 & 0.93 & 0.94 & 0.92 & 0.92 & 0.90 \\
\hline AGFI & 0.91 & 0.89 & 0.92 & 0.89 & 0.92 & 0.90 & 0.91 & 0.89 & 0.88 & 0.87 \\
\hline CFI & 0.97 & 0.96 & 0.98 & 0.96 & 0.98 & 0.97 & 0.98 & 0.96 & 0.95 & 0.94 \\
\hline IFI & 0.97 & 0.96 & 0.98 & 0.96 & 0.99 & 0.97 & 0.98 & 0.96 & 0.95 & 0.94 \\
\hline MIFI & 0.93 & 0.89 & 0.95 & 0.90 & 0.96 & 0.92 & 0.94 & 0.90 & 0.85 & 0.79 \\
\hline RMSEA & 0.005 & 0.046 & 0.037 & 0.040 & 0.032 & 0.040 & 0.041 & 0.045 & 0.058 & 0.057 \\
\hline
\end{tabular}

$\alpha$ significance: $+10 \% ; * 5 \%$; ** $1 \%$

Table 6. Results for models 2 and 3

The analysis of the first mediation block (models 1, 2 and 3) shows that the direct relationships between

\footnotetext{
${ }^{6}$ All the constructs were calculated as the mean of the items in the construct. For EC, CI, SI, EIO and INTI construct values scaled from 1 to 7 , for all other constructs values scaled from 1 to 5 .
} 
SI and EIO and between CI and EIO are significant, positive and with a path of 0.473 and 0.169 , respectively (model 1, Table 9). This supports H3 and H4. Meanwhile, the direct relationships between SI or CI and the performance measures are only significant in the case of customer satisfaction (model 2, Table 6) with values of 0.503 for CI and 0.178 for SI. Therefore hypotheses H6 and H7 have only been supported for customer satisfaction and not for operational performance (flexibility, delivery, inventory and quality). With respect to the relationship between EIO and performance, the paths are significant and positive for flexibility, delivery, inventory and quality, but negative for customer satisfaction (model 3, Table 6). In this case, H8 is accepted for all the performance measures except customer satisfaction. These results mean that the mediation of EIO between SI or CI and the operational performance measures can be considered. There is no mediation with regard to customer satisfaction, and the relationship between EIO and customer satisfaction sustains a negative net suppression when the direct relationships of SI and CI with customer satisfaction are included. As these direct relationships are significant, we shall only consider the direct relationship between SI and CI and customer satisfaction in subsequent models. To conclude, hypotheses H9 and H10 have been supported for operational performance but not for customer satisfaction.

\begin{tabular}{|l|l|l|l|l|l|l|}
\hline & Mod 1 & Mod 4 & Mod 5 & \multicolumn{1}{c|}{ Mod 6 } & Mod 7 & Final model \\
\hline Chi2 & 140.3 & 269.07 & 507.60 & 232.65 & 53.92 & 521.40 \\
\hline Df & 85 & 129 & 301 & 85 & 25 & 311 \\
\hline Sig & 0.000 & 0.000 & 0.000 & 0.000 & 0.001 & 0.000 \\
\hline GFI & 0.93 & 0.871 & 0.847 & 0.862 & 0.955 & 0.844 \\
\hline AGFI & 0.90 & 0.829 & 0.808 & 0.806 & 0.918 & 0.811 \\
\hline CFI & 0.96 & 0.914 & 0.914 & 0.893 & 0.964 & 0.912 \\
\hline IFI & 0.96 & 0.815 & 0.915 & 0.894 & 0.965 & 0.913 \\
\hline MIFI & 0.90 & 0.737 & 0.637 & 0.724 & 0.946 & 0.632 \\
\hline RMSEA & 0.050 & 0.069 & 0.055 & 0.087 & 0.067 & 0.054 \\
\hline
\end{tabular}

Table 7. Goodness-of-fit of models 1, 4, 5, 6, 7 and the final model

Similarly, the second mediation block tests hypotheses H1, H2, H5 and H11 by analysing models 1, 3 and 4. The direct relationships between INTI and SI or CI is significant, with paths of 0.447 and 0.604 , respectively (model 1, Table 9). This confirms hypotheses $\mathrm{H} 1$ and H2. Likewise, INTI has a direct and significant effect on all the performance measures. The value of the paths is 0.60 for customer satisfaction, slightly over 0.40 for delivery, flexibility and quality and 0.30 for inventory (model 4 , Table 8 ). Despite the fact that model 4 presents a poor fit (Table 7), all the estimated factor loadings were significant and the paths have values that are consistent with those in model 3, which presents a good fit. As such, the data support H5.

If we compare the values of the direct effects of INTI on performance with the constructs relative to EI (SI/CI/EIO) not included in the model (model 4 in Table 8) with the direct effects in the model with the mediation block (EI) included (model 3 in Table 6), we see that there is partial mediation in flexibility, quality and customer satisfaction (the direct effects are reduced but they continue to be significant and, therefore, there is a direct effect between INTI and these performance measures, and a separate indirect effect through EI (SI/CI/EIO)). In other respects, mediation is full in delivery and inventory. This confirms H11.

\begin{tabular}{|c|c|c|c|c|c|c|c|c|c|c|}
\hline \multirow[t]{2}{*}{$\begin{array}{l}\text { Dependent } \\
\text { variable } \rightarrow\end{array}$} & \multicolumn{2}{|c|}{ Delivery } & \multicolumn{2}{|c|}{ Flexibility } & \multicolumn{2}{|c|}{ Inventory } & \multicolumn{2}{|c|}{ Quality } & \multicolumn{2}{|c|}{$\begin{array}{c}\text { Customer } \\
\text { Satisfaction }\end{array}$} \\
\hline & Mod 4 & Mod 5 & Mod 4 & Mod 5 & Mod 4 & Mod 5 & Mod 4 & Mod 5 & Mod 4 & Mod 5 \\
\hline CI-Perf & $-\cdots$ & -- & $-\cdots$ & --- & $-\cdots$ & $\begin{array}{ll}-- \\
\end{array}$ & -- & $-\cdots$ & $\begin{array}{ll}-- \\
\end{array}$ & $0.495^{* * 4}$ \\
\hline SI-Perf & $-\cdots$ & $-\cdots$ & $-\cdots$ & $\cdots$ & $-\cdots$ & $\cdots$ & $-\cdots$ & $-\cdots$ & $\cdots$ & $0.206^{* * *}$ \\
\hline EIO-Perf & 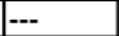 & $0.521 * *$ & --- & $0.399 * *$ & -.. & $0.426^{* * *}$ & --- & $0.439 * *$ & -- & - \\
\hline INTI-Perf & $0.419^{* * *}$ & $0.293^{*} *$ & $0.440^{* * *}$ & $0.230^{*}$ & $0.303^{*}$ & -0.005 & $0.401^{* * *}$ & 0.016 & $0.601 * *$ & 0.106 \\
\hline EC-Perf & \begin{tabular}{|l|}
-- \\
\end{tabular} & $-0.192^{*}$ & $\begin{array}{ll}-- \\
\end{array}$ & 0.064 & $-\cdots$ & 0.022 & \begin{tabular}{|l|}
-- \\
\end{tabular} & 0.145 & $\begin{array}{ll}-- \\
\end{array}$ & $0.165^{*}$ \\
\hline \begin{tabular}{|l|} 
CI-EIO \\
\end{tabular} & $-\cdots$ & $0.156+$ & $-\cdots$ & $0.156+$ & -- & $0.156+$ & $-\cdots$ & $0.156+$ & $-\cdots$ & $0.156+$ \\
\hline \begin{tabular}{|l|} 
SI-EIO \\
\end{tabular} & $-\cdots$ & $0.412^{* * *}$ & $--\cdot$ & $0.412^{* * *}$ & $-\cdots$ & $0.412^{* * *}$ & -- & $0.412^{* *}$ & -- & $0.412^{* * 4}$ \\
\hline INTI-CI & --- & $0.574 * *$ & -- & $0.574^{* * *}$ & $-\cdots$ & $0.574^{* * *}$ & --- & $0.574 * *$ & $--\cdot$ & $0.574^{* * 4}$ \\
\hline EC-CI & $-\cdots$ & 0.017 & $-\cdots$ & 0.017 & $\ldots$ & 0.017 & $-\cdots$ & 0.017 & -- & 0.017 \\
\hline INTI-SI & $-\cdots$ & $0.348^{* * *}$ & --- & $0.348^{* * *}$ & $\ldots$ & $0.348^{* * *}$ & $-\cdots$ & $0.348 * *$ & $-\cdots$ & $0.348^{* * 4}$ \\
\hline EC-SI & \begin{tabular}{|l|}
-- \\
\end{tabular} & 0.153 & --- & 0.153 & $-\cdots$ & 0.153 & --- & 0.153 & --- & 0.153 \\
\hline EC-INTI & $0.675^{* *}$ & $0.641 * *$ & $0.675^{* * *}$ & $0.641 * *$ & $0.675^{* * *}$ & $0.641^{* * *}$ & $0.675^{* *}$ & $0.641 * *$ & $0.675^{* *}$ & $0.641^{* * *}$ \\
\hline $\mathbf{R}^{2}$ & 0.176 & 0.363 & 0.194 & 0.235 & 0.092 & 0.185 & 0.161 & 0.248 & 0.362 & 0.572 \\
\hline
\end{tabular}

$\alpha$ significance: $+10 \%$; $* 5 \%$;* $1 \%$

Table 8. Results for models 4 and 5 
For the third mediation block, which tests hypotheses H13 to H17, we shall use models 1, 5 and 7, which present fit indices that can be considered acceptable on the whole (Table 7). The direct relationship between EC and INTI is significant with a path of 0.636 (model 1, Table 9), which confirms H13. Similarly, the direct relationships between EC and CI or SI are significant, with paths of 0.385 and 0.349 , respectively (model 7 , Table 9), which enables hypotheses $\mathrm{H} 14$ and $\mathrm{H} 15$ to be confirmed. If we compare the values of the direct relationship between EC and CI or SI in model 5, which includes construct INTI as a mediator (0.017 and 0.153, respectively, neither of which are significant in Table 8), with those of model 7 (Table 9), it can be observed that there is full mediation of INTI, the presence of which in the model prevents the direct relationship from being significant when INTI is included as the mediator. All this allows us to confirm that EC explains INTI directly and it is through INTI that it acts on the components of EI. As a result, these data enable us to support H16 and H17.

Lastly, the fourth mediation block uses models 4, 5 and 6 to test H12 and H18. EC presents a direct relationship with the performance measures if no other construct is included in the model. The path values are significant, with values of 0.205 for delivery, 0.252 for inventory, 0.353 for flexibility, 0.359 for quality, and 0.505 for customer satisfaction (model 6, Table 9). These data confirm H12 for all the performance measures.

In other respects, model 4 (Table 8) confirmed the direct relationship between EC and INTI and between INTI and the performance measures. Comparing the direct relationships between EC and the performance measures when no other constructs are included (model 6, Table 9) with the direct relationships between EC and performance measures when the remaining constructs are included (model 5, Table 8), it can be seen that SCI (INTI/SI/CI/EIO) acts as a full mediator for EC in flexibility, inventory and quality, as when SCI is included in model 5 the significant paths are no longer significant. This generates negative net suppression for delivery (the direct relationship changes its arithmetical sign and the direct effects of INTI and EIO increase compared to model 3, Table 6). If we therefore eliminate this direct relationship from the final model it will be fully mediated. As far as customer satisfaction is concerned, SCI produces partial mediation, reducing the direct effect of EC on performance, but without cancelling it out or making it non significant. For all these reasons we can therefore consider that $\mathrm{H} 18$ has been confirmed.

\begin{tabular}{|l|l|l|l|l|l|l|l|}
\hline $\begin{array}{c}\text { Dependent } \\
\text { construct } \rightarrow\end{array}$ & $\begin{array}{c}\text { EIO } \\
\text { Mod 1 }\end{array}$ & $\begin{array}{c}\text { Delivery } \\
\text { Mod 6 }\end{array}$ & $\begin{array}{c}\text { Flexibility } \\
\text { Mod 6 }\end{array}$ & $\begin{array}{c}\text { Inventory } \\
\text { Mod 6 }\end{array}$ & $\begin{array}{c}\text { Quality } \\
\text { Mod 6 }\end{array}$ & $\begin{array}{c}\text { Customer } \\
\text { Satisfaction } \\
\text { Mod 6 }\end{array}$ & $\begin{array}{c}\text { CI/SI } \\
\text { Mod 7 }\end{array}$ \\
\hline EC-Perf & --- & $0.205^{* *}$ & $0.353^{* *}$ & $0.252^{* *}$ & $0.359^{* *}$ & $0.505^{* *}$ & --- \\
\hline CI-EIO & $0.169^{*}$ & --- & --- & --- & --- & --- & --- \\
\hline SI-EIO & $0.473^{* *}$ & --- & --- & --- & --- & --- & --- \\
\hline INTI-CI & $0.604^{* *}$ & --- & --- & --- & --- & --- & --- \\
\hline EC-CI & --- & -- & --- & --- & --- & --- & $0.385^{* *}$ \\
\hline INTI-SI & $0.447^{* *}$ & --- & --- & --- & --- & --- & --- \\
\hline EC-SI & --- & --- & --- & --- & --- & --- & $0.349^{* *}$ \\
\hline EC-INTI & $0.636^{* *}$ & --- & --- & --- & --- & -- & - \\
\hline$R^{2}$ & 0.296 & 0.042 & 0.124 & 0.064 & 0.129 & 0.225 & 0.148 (for CI) \\
\hline
\end{tabular}

$\alpha$ significance: $+10 \%$; $* 5 \%$; * $1 \%$

Table 9. Results for models 1, 6 and 7

Given all the above results, the final model was established on the basis of model 5 and omitting all the non significant paths (EC-->flexibility, EC-->inventory, EC-->quality, EC-->CI, EC-->SI, INTI-->Inventory, INTI--> quality, INTI-->Customer satisfaction) and those that cause a negative net suppression effect (EC->Delivery, INTI-->Delivery). The final model presents a similar fit to model 5. The standardised paths are shown in Table 10. These data enable the direct and indirect effects of the different constructs on the performance measures to be calculated (Table 11). The final model explains $37.6 \%$ of variance in delivery, $25.1 \%$ in flexibility, $20.4 \%$ in inventory, $27.0 \%$ in quality and $57.5 \%$ of variance in customer satisfaction. 


\begin{tabular}{|l|l|l|l|l|l|}
\hline $\begin{array}{c}\text { Dependent } \\
\text { construct }\end{array}$ & $\begin{array}{c}\text { Delivery } \\
\text { Final model }\end{array}$ & $\begin{array}{c}\text { Flexibility } \\
\text { Final model }\end{array}$ & $\begin{array}{c}\text { Inventory } \\
\text { Final model }\end{array}$ & $\begin{array}{c}\text { Quality } \\
\text { Final model }\end{array}$ & $\begin{array}{c}\text { Customer } \\
\text { Satisfaction } \\
\text { Final model }\end{array}$ \\
\hline EIO-Perf & $0.613^{* *}$ & $0.386^{* *}$ & $0.451^{* *}$ & $0.519^{* *}$ & --- \\
\hline CI-Perf & --- & --- & --- & --- & $0.540^{* *}$ \\
\hline SI-Perf & --- & -- & --- & -- & $0.219^{* *}$ \\
\hline INTI-Perf & --- & $0.222^{* *}$ & --- & --- & --- \\
\hline EC-Perf & --- & --- & --- & --- & $0.215^{* *}$ \\
\hline CI-EIO & $0.198^{*}$ & $0.198^{*}$ & $0.198^{*}$ & $0.198^{*}$ & $0.198^{*}$ \\
\hline SI-EIO & $0.393^{* *}$ & $0.393^{* *}$ & $0.393^{* *}$ & $0.393^{* *}$ & $0.393^{* *}$ \\
\hline INTI-CI & $0.603^{* *}$ & $0.603^{* *}$ & $0.603^{* *}$ & $0.603^{* *}$ & $0.603^{* *}$ \\
\hline EC-CI & ------- & -- & - \\
\hline INTI-SI & $0.478^{* *}$ & $0.478^{* *}$ & $0.478^{* *}$ & $0.478^{* *}$ & $0.478^{* *}$ \\
\hline EC-SI & -------- & - & - \\
\hline EC-INTI & $0.657^{* *}$ & $0.657^{* *}$ & $0.657^{* *}$ & $0.657^{* *}$ & $0.657^{* * *}$ \\
\hline$R^{2}$ & 0.376 & 0.251 & 0.204 & 0.270 & 0.575 \\
\hline
\end{tabular}

Table 11 summarises the effects of the constructs analysed. Following Chin (1988), a $>0.20$ path can be considered strong (as opposed to simply statistically significant). In this case, there are strong direct relationships between EIO and delivery, quality, inventory and flexibility. CI only shows strong direct effects on customer satisfaction and does not appear to strongly affect the other performance measures. However, SI presents a strong direct effect on customer satisfaction and moderate indirect effects on flexibility and inventory; a strong indirect effect on delivery and quality. Meanwhile, INTI presents strong direct and full effects on flexibility. Its indirect effects on the performance variables are strong on customer satisfaction and moderate on delivery, inventory and quality. EC has strong direct and indirect effects on customer satisfaction and a moderate indirect effect on delivery and flexibility.

\begin{tabular}{|c|c|c|c|c|c|}
\hline & Delivery & Flexibility & Inventory & Quality & Customer Satisf. \\
\hline EIO & $\begin{array}{l}\text { Significant direct } \\
\text { path } 0.613\end{array}$ & $\begin{array}{l}\text { Significant direct } \\
\text { path: } 0.386\end{array}$ & $\begin{array}{l}\text { Significant direct } \\
\text { path } 0.451\end{array}$ & $\begin{array}{l}\text { Significant direct } \\
\text { path } 0.519\end{array}$ & $\begin{array}{l}\text { Non Significant } \\
\text { direct path. }\end{array}$ \\
\hline CI & $\begin{array}{l}\text { Non Significant } \\
\text { direct path. } \\
\text { Indirect path } \\
0.121\end{array}$ & $\begin{array}{l}\text { Non Significant } \\
\text { direct path. } \\
\text { Indirect path } \\
0.076\end{array}$ & $\begin{array}{l}\text { Non Significant } \\
\text { direct path. } \\
\text { Indirect Path } \\
0.089\end{array}$ & $\begin{array}{l}\text { Non Significant } \\
\text { direct path. } \\
\text { Indirect path } \\
0.103\end{array}$ & $\begin{array}{l}\text { Significant direct } \\
\text { path } 0.540\end{array}$ \\
\hline SI & $\begin{array}{l}\text { Non Significant } \\
\text { direct path. } \\
\text { Indirect path } \\
0.241\end{array}$ & $\begin{array}{l}\text { Non Significant } \\
\text { direct path. } \\
\text { Indirect path } \\
0.152\end{array}$ & $\begin{array}{l}\text { Non Significant } \\
\text { direct path. } \\
\text { Indirect path } \\
0.177\end{array}$ & $\begin{array}{l}\text { Non Significant } \\
\text { direct path. } \\
\text { Indirect path } \\
0.204\end{array}$ & $\begin{array}{l}\text { Significant direct } \\
\text { path } 0.219\end{array}$ \\
\hline INTI & $\begin{array}{l}\text { Non Significant } \\
\text { direct path. } \\
\text { Indirect path } \\
0.188\end{array}$ & $\begin{array}{l}\text { Significant direct } \\
\text { path } 0.222 \\
\text { Indirect path } \\
0.119 \\
\text { Total path: } 0.341\end{array}$ & $\begin{array}{l}\text { Non Significant } \\
\text { direct path. } \\
\text { Indirect path } \\
0.139\end{array}$ & $\begin{array}{l}\text { Non Significant } \\
\text { direct path. } \\
\text { Indirect path } \\
0.159\end{array}$ & $\begin{array}{l}\text { Non Significant } \\
\text { direct path. } \\
\text { Indirect path } \\
0.430\end{array}$ \\
\hline $\mathbf{E C}$ & $\begin{array}{l}\text { Non Significant } \\
\text { direct path. } \\
\text { Indirect path } \\
0.107\end{array}$ & $\begin{array}{l}\text { Non Significant } \\
\text { direct path. } \\
\text { Indirect path } \\
0.193\end{array}$ & $\begin{array}{l}\text { Non Significant } \\
\text { direct path. } \\
\text { Indirect path } \\
0.079\end{array}$ & $\begin{array}{l}\text { Non Significant } \\
\text { direct path. } \\
\text { Indirect path } \\
0.090\end{array}$ & $\begin{array}{l}\text { Significant direct } \\
\text { path } 0.215 \\
\text { Indirect path } \\
0.244 \\
\text { Total path: } 0.459\end{array}$ \\
\hline
\end{tabular}

Table 11. Direct and indirect paths (Standardised loads)

As can be seen in Table 12, the majority of the hypotheses tested have been supported. The findings will be discussed in the following section. 


\begin{tabular}{|l|l|}
\hline Hypothesis & Result \\
\hline H1, H2, H3, H4 & Supported \\
\hline H5 & Supported for all the performance measures \\
\hline H6, H7 & $\begin{array}{l}\text { Supported for customer satisfaction } \\
\text { Not supported for delivery, flexibility, inventory and quality }\end{array}$ \\
\hline $\mathbf{H 8 , ~ H 9 , ~ H 1 0 ~}$ & $\begin{array}{l}\text { Supported for flexibility, delivery, inventory and quality } \\
\text { Not supported for customer satisfaction }\end{array}$ \\
\hline H11 & $\begin{array}{l}\text { Supported } \\
\text { * Full mediation for delivery and inventory } \\
\text { * Partial mediation for flexibility, quality and customer satisfaction }\end{array}$ \\
\hline H12 & Supported for all the performance measures \\
\hline H13, H14, H15 & Supported \\
\hline H16, H17 & Supported full mediation) \\
\hline H18 & $\begin{array}{l}\text { Supported with: } \\
\text { * Full mediation for delivery, flexibility, inventory and quality } \\
\text { * Partial mediation for customer satisfaction }\end{array}$ \\
\hline & Table 12: Conclusions of hypothesis testing \\
\hline
\end{tabular}

\section{Discussion and conclusions}

\subsection{Research findings and the previous literature}

The hypotheses H1 to H4 have been supported. This implies that the higher the level of INTI, the higher the levels of CI and SI. In other respects, the existence of SI and CI helps the firm to believe in EI's strategic importance (EIO) and this contributes to its future strategies continuing to seek collaborative relationships with suppliers and customers rather than adversarial relationships, in their quest for generating processes with added value that enable them to achieve sustainable competitive advantages (Porter, 1986). The hypotheses tested provide new empirical evidence and respond to the call for more research on this topic (Zhao et al., 2011; Kim, 2013; Alfalla-Luque et al., 2013a). The results are in line with previous empirical research that found a significant positive correlation between INTI and EI (Gimenez \& Ventura, 2005; Koufteros et al., 2005; Eng, 2006; Koufteros et al., 2010; Zhao et al., 2011; Baihaqi \& Sohal, 2013). INTI seems to be the starting point for broader integration across the SC (Harrison \& Van Hoek, 2005).

The direct and mediated effects of INTI and EI dimensions on the performance measures have also been analysed. As explained in section 2, the previous literature is not in complete agreement on this point. The findings of this research show that INTI has a direct and significant positive effect on all the performance measures (H5). This result is consistent with several studies (Droge et al., 2004; Stank et al., 2001; Germain \& Iyer, 2006; Flynn et al., 2010; Huo, 2012; Liu et al., 2012; Zhao et al., 2013; Danese et al., 2013).

The direct relationships between SI and CI and performance are only significant for customer satisfaction (H6 and H7). However, the presence of EIO directly affects all the performance measures except customer satisfaction (H8). EIO is therefore the element that generates the organisation's strategic commitment to suppliers and customers and enables "operational" efficiency to be improved. This is consistent with Swink et al. (2007) when they state that the simultaneous strategic integration of customers and suppliers is considered to be a necessary condition for ensuring the achievement of significant benefits. This seems to show the importance of including the EI strategic vision with respect to both customers and suppliers (EIO) achieving operational results compared to either SI or CI individually. On the other hand, customer satisfaction seems to be directly linked to the existence of SI or CI. In line with the RBV, EIO could be considered one of the core capabilities (Bowersox et al., 2000) that provide greater benefits than adversarial relationships (Whipple et al., 2010). Like the present research, some studies found that CI did not have a significant direct effect on operational performance (Devaraj et al., 2007; Danese \& Romano, 2011; Danese \& Romano, 2013) and that CI and SI have a positive effect on customer satisfaction (significantly higher for CI) (Zhao et al., 2013). Furthermore, there has also been support for SI not being directly related to operational performance (Stank et al., 2001; Koufteros et al., 2007; Song \& Thieme, 2009, Flynn et al., 2010).

If we were only to take these direct relationships into account, the above results would be the definitive findings, but, as we have demonstrated, some of the relationships are mediated. As Jin et al. (2013) suggest, a possible origin of the lack of consensus on the relationships between SCI dimensions and performance is that these relationships could be nuanced. Indeed, EIO acts as a mediator in the relationship between SI or CI and the operational performance measures, but not customer satisfaction (H9 and H10). It is therefore the inclusion of EIO, considering both suppliers and customers, what seems to generate an indirect effect 
between SI or CI and the improvement in operational performance. The full mediation of EI (SI/CI/EIO) between INTI and delivery and inventory, and a partial mediation for flexibility, quality and customer satisfaction (H11) have also been confirmed. In consequence, EI channels the effect of INTI and allows improvements to all the performances measures (with full or partial mediation). In other words, there are two indirect paths between INTI and all the performance measures (P), which goes through SI (INTI-->SI->EIO-->P) and CI (INTI-->CI-->EIO-->P) and, at the same time there is also a direct effect on some performance measures (customer satisfaction, flexibility and quality). These findings seem to show that INTI plays a direct role in achieving higher customer satisfaction, higher flexibility and better quality. However, the importance of INTI's direct role recedes while EI gains in importance for explaining the improvement in delivery and inventory. To put it another way, the initially identified INTI direct relationship disappears when EI is included in the model, and EI acts with the full mediation of delivery and inventory. The SCI dimensions are therefore not independent of each other. These results are in line with Gimenez \& Ventura (2005), who found that EI mediates the relationship between INTI and operational performance measures.

However, the proposed model becomes even more complex when we include the analysis of the influence that EC has as an antecedent of the relationship between SCI and performance. This paper confirms the existence of the direct relationship between EC and performance (H12) when no other constructs are identified as possibly mediating in this relationship. This result is consistent with the widely-accepted conclusions found in the literature that determine that EC contributes to better operational performance (Guest, 2001; Samad, 2013; Boselie et al., 2005; Paul \& Anantharaman, 2003; Young \& Choi, 2011; Katou 2011; Brown et al., 2011; Vanichchinchai, 2012) and customer satisfaction (Moynihan et al., 2001; Nishii et al., 2008).

However, EC's influence on performance could be nuanced by other factors in the company, such as SCI. Responding to the call for knowledge of how this relationship is produced (Cua et al. 2001), SCI has been included as the mediator in the analysis. The results show that EC has a direct effect on INTI (H13). Having a committed workforce helps to achieve adequate INTI. Meanwhile, EC's influence on SI and CI is confirmed if the analysis of INTI is not included (H14 and H15). This result is consistent with the prior literature (Koulikoff-Souviron \& Harrison, 2007; Vanichchinchai, 2012). However, when the way that these four aspects interact is analysed in a more complex model, the full mediation of INTI in the relationship between EC and SI (H16) and CI (H17) is confirmed, while the direct relationship disappears. This indicates that the contribution of EC to greater SI and CI is due to the existence of INTI. As Mentzer et al. (2001) stated, commitment is a precondition that needs to be in place in order for a company to achieve inter-firm coordination, and without INTI, EI cannot achieve its full potential. Our findings state that EC directly benefits INTI and EI through INTI. EC therefore contributes to SCI through INTI (Vanichchinchai \& Igel, 2011).

When these results are compared to the relationships identified in the analysis of the SCI dimensions and performance, a model is identified in which EC helps SCI to be achieved through its influence on INTI. INTI in turn contributes to better performance being obtained both directly and through its mediating influence on EI. EI also contributes to performance. This would mean that SCI is mediating the relationship between EC and performance (H18). The results confirm a full mediation of SCI in the relationship of EC with each of the operational performance measures. Having committed employees is therefore an important element for SCI to achieve better results in delivery, flexibility, inventory and quality. However, SCI mediation is partial for customer satisfaction, as EC has a strong direct effect.

The mediation detected between EC and performance confirms the results of Gowen III \& Tallon (2003) and is consistent with past studies on EC that indicate that it is crucial for the success of SCM (Dooley \& Fryxell, 1999; Dow et al., 1999). Furthermore, the contribution that EC makes to better SCI plays a core role in mitigating the adverse impact of SC implementation barriers on the success of SC practices (Gowen III \& Tallon, 2003). It is thus clear that it is necessary to focus on the workforce management factor to obtain an added advantage/improvement that can become the source of competitive advantage for the organisation and the SC. This paper confirms these results by demonstrating that EC, a main outcome of workforce management, benefits SCI and, through SCI, improves operational performance. Vanichchinchai (2012) identified that the relationship between EC and performance was mediated by EI. Our research completes the relationships identified by said author as his model did not consider INTI.

Our results therefore confirm previous research (Pandey et al., 2012; Gowen III \& Tallon, 2003; Vanichchinchai \& Igel, 2011; Vanichchinchai, 2012) and contribute greater evidence by specifying a more complex model which verifies the existence of intermediate variables to explain the relationships that enable organisational performance to be improved through workforce management and SCI. Fawcett et al. (2008) 
state that workforce management will not only bridge the current gaps encountered in SCM but allow success to be improved and greater rewards of SC to be reaped. So, one of the pillars of SCM success is founded on people.

Summarising our final model, we conclude that:

(1) The relationship between EC and the other research constructs is entirely mediated by INTI, except for the relationship with customer satisfaction, on which it has strong direct and indirect effects. The relationship between EC and operational performance is fully mediated by SCI, which it affects through INTI, with the moderate indirect effects of EC on delivery and flexibility standing out. In consequence, EC plays a key role in explaining the results obtained with the implementation of SCI.

(2) EC is necessary for INTI to be achieved effectively, and INTI affects performance both directly and indirectly. INTI has a direct strong effect on flexibility. However, as we have identified that EI (SI/CI/EIO) mediates the relationship between INTI and performance, INTI contributes to customer satisfaction with a strong indirect effect through EI and to operational performance with a moderate indirect effect.

(3) With respect to EI, INTI is necessary for EI to achieve results. We have identified that EIO mediates the relationships of both SI and CI with performance. SI and CI only have a direct influence on customer satisfaction and they have a strong effect. The indirect effect of SI is strong on delivery and quality and moderate on flexibility and inventory. Meanwhile, CI affects operational performance indirectly and delivery and quality moderately. Finally, EIO has a strong direct effect on all operational performance measures, but no relationship is identified with customer satisfaction.

(4) All the relationships between EC, SCI dimensions and performance analysed in the final model explain $37.6 \%$ of variance in delivery, $25.1 \%$ in flexibility, $20.4 \%$ in inventory, $27.0 \%$ in quality and $57.5 \%$ of variance in customer satisfaction (Table 10).

\subsection{Contributions}

This research makes several contributions. Firstly, this study has contributed to filling the gap that exists in the relationships (direct and mediated) between EC, SCI (considering its dimensions) and performance (Shub \& Stonebraker, 2009; Fisher et al., 2010). The final model contributes new evidence to the literature, analysing a complex model that relates a set of variables that to date had not been studied jointly or in such detail. Workforce management has not been greatly addressed in OM research and very few studies have analysed SCI acting as a mediator between EC and performance (Gowen III \& Tallon, 2003; Vanichchinchai, 2012). In general terms, the paper attempts to clarify the mediating effects of SCI between EC and performance in a definitive model that nuances the direct relationships initially found.

Secondly, this study contributes to the literature by providing a detailed study of the direct and indirect effect of each SCI dimension on each performance measure. Different models were created for this that enabled the way that the relationships became nuanced to be observed as mediating constructs and antecedents were added. With this we provide empirical evidence that can explain the heterogeneous results in the prior research that analyses the relationship between SCI and performance.

Thirdly, the paper analyses SCI not as a single construct, but distinguishing between its various dimensions, including INTI, which has been excluded from many papers (Flynn et al., 2010). This research reinforces the key role of INTI in achieving EI and performance. It also demonstrates the important role of EIO in improving operational performance.

Finally, the performance measures have been analysed independently and this enables the influence that EC and SCI dimensions have on each measure to be seen, as well as more detailed results to be achieved than if performance were analysed in aggregate terms.

\subsection{Implications for managers}

From a practical standpoint, our research offers managers evidence of the benefits of EC as an antecedent of SCI. Firms could achieve a greater competitive advantage by improving their EC and SCI. In this regard, senior management should pay special attention to EC and INTI to achieve all the performance potential that SCI is capable of, whilst also being mindful that EC is a social process that is built up over a long period of time. The results show that if a firm achieves EC and SCI this will impact on all the performance measures (Table 10). The strongest impact will be on customer satisfaction. Although there will be less impact on delivery, quality, flexibility and, finally, on inventory, it will nonetheless be sufficiently strong. KoulikoffSouviron \& Harrison (2007) stress the central role of workforce practices in supporting and operationalising 
SC relationships, but also point out that, despite this, Human Resources managers are barely involved in the management of these relationships. In this line, McCarter et al. (2005) state that managers assert that workforce management is fundamental for the success of SCI but, in practice, priority is given to technical questions, and this huge potential is lost. It would therefore seem that greater importance should be placed on workforce management in the process to accomplish SCI. Studies such as that which we present here confirm the need for genuinely undertaking the practice of workforce management and coordinating it with SCM in order to achieve EC given the evident benefits that it provides to the firm. EC can be developed through the implementation or deployment of High Commitment Work Practices, such as job-based skill training, formal performance management, job security, job enrichment, work teams, and suggestion systems. All these practices aim to drive up skill levels, motivation and empowerment, which are the levers that deploy worker commitment (Guest, 2001; Patterson et al., 2010; Marin-Garcia, 2013).

As we have demonstrated, by achieving EC the firm contributes to improving INTI and by obtaining INTI it helps to achieve SI and CI. The results indicate that neither CI nor SI on its own is enough to improve operational performance, but that EIO is necessary for the organisation to achieve improvements in operational performance. As a result, companies should strive to achieve both EC and INTI as they mutually reinforce each other. Similarly, managers should achieve INTI before EI and include EI at the strategic level in order to reap the greatest advantages from SCI. Meanwhile, managers should promote EC not only for better SC success but also to mitigate the barriers of SCM implementation (Gowen III \& Tallon, 2003).

\subsection{Limitations and future research}

As with all empirical research, our study has its limitations. Firstly, we share one limitation with the majority of studies undertaken in the area. We use cross-data and, although we have used the causality sequence proposed in the prior literature, we are fully aware that this type of data does not enable the direction of the causality to be fully tested. Secondly, we have assumed that EC fully mediates workforce management, not only with respect to performance, which is an aspect on which evidence can be found in the prior literature, but also with respect to SCI. This last point has not been the object of study in the references found.

The data set used was collected during the 2005-2008 period. Since then, the deployment levels of the constructs analysed may have changed. In other words, it is very likely that the mean scores of the constructs will have varied during this time. One reason for this might be evolving technology; another, the worldwide economic crisis that has affected all the countries in the sample population and all productive sectors, impacting especially on the three sectors in the sample used here. Nonetheless, the objectives of this research would seem to indicate that, rather than any changes in the deployment levels of each of the practices, what might be a limitation of the study is that the measurement or structural invariance between the date on which the data were collected and a sample taken at the present time might not be complied with. In other words, the relationships between the constructs may have changed due to the new technologies facilitating greater internal integration or integration with customers and suppliers, or due to the economic crisis, or some other variable that constitutes a change of paradigm between 2005-2008 and the current time. It would be of great interest to develop future research with a study using new data, which would address this issue by analysing whether the more widespread use of information technologies or undergoing deep and long-lasting crises have any effects on construct loads.

Another limitation is that the data are taken from three industries (electronics, machinery, and automotive components) that all produce manufacturing products. The results should therefore be analysed in the context of these sectors, and the results cannot be stated to hold in other contexts. However, this research is based on a powerful data set, which allows many of the limitations of previous studies to be overcome, including those linked to multiple-informant data gathering, sample size, the breadth of the set of variables envisaged, the use of reliable multi-item scales and a sampling design by industry and country.

This study's proposed further research model focuses on two elements, firstly by extending the analysed model to the left to include workforce management practices as an antecedent of EC. This would enable an analysis to be done of whether EC mediates the relationship between workforce management practices and SCI and performance (as we have assumed on the basis of the existing prior literature), thus allowing empirical evidence to be provided as to whether this mediation exists or not and, if it does, whether it is full or partial. Secondly, it would be desirable to extend the model to the right to take in financial performance measures and to analyse whether operational performance mediates the relationship between SCI and financial performance, as the prior literature states. The proposed model would thus be completed and include new causality relationships that would allow advances to be made in the field. 
The review of the previous literature on this topic shows that research has mainly focused on the manufacturing sector, so it would be interesting to analyse the proposed research model in the services sector and to conduct a comparative intersectoral analysis. Also, given the prior literature's lack of consensus on the results, it would be interesting to carry out qualitative research (case studies) to help theory building in the field.

In other respects, as stated in the literature review, a reason for the lack of consensus in prior empirical research on how SCI affects performance could be that SCI does not have the same impact on performance depending on the country, industry, plant age, product complexity or plant size. In consequence, further research will go deeper into the analysis in an attempt to clarify the specific contexts in which achieving SCI may not be interesting for improving organisational performance and competitive advantages.

\section{Acknowledgments}

This paper has been made possible thanks to grant DPI2009-11148 and DPI2010-18243 awarded by the Spanish Ministry of Science and Innovation and the Project of Excelence P08 SEJ 3841 awarded by the Junta de Andalucia.

\section{References}

Alfalla-Luque, R., Medina-Lopez, C., 2009. Supply Chain Management: unheard of in the 1970s, core to today’s company. Business History, 51(2), 202-221.

Alfalla-Luque, R., Marin-Garcia, J.A., Medina-Lopez, C., 2012. Is worker commitment necessary for achieving competitive advantage and customer satisfaction when companies use HRM and TQM practices? Universia Business Review, 36, 64-89.

Alfalla-Luque, R., Medina-Lopez, C., Dey, P.K., 2013a. Supply chain integration framework using literature review. Production Planning and Control, 24(8-9), 800-817.

Alfalla-Luque, R., Medina-Lopez, C., Schrage, H., 2013b. A study of supply chain integration in the aeronautics sector. Production Planning and Control, 24(8-9), 769-784.

Allred, C.R., Fawcett, S.E., Wallin, C., 2011, The evolving role of a collaboration orientation in mitigating functional and inter-organizational conflict. Decision Sciences Journal, 42(1), 129-161.

Alto, M., Vallejo, G., 2011. Los efectos de terceras variables en la investigación psicológica. Anales de Psicología, 27(2), 550-561.

Anderson, J.C., Gerbing, D.W., 1988. Structural equation modelling in practice: a review and recommended two-step approach. Psychological Bulletin, 103(3), 411-23.

Bagchi, P.K., Ha, B.C., Skjoett-Larsen, T., Soerensen, L.B., 2005. Supply chain integration: a European survey. The International Journal of Logistic Management, 16(2), 275-294.

Bagozzi, R.P., Yi, Y.J., Phillips, L.W., 1991. Assessing construct-validity in organizational research. Administrative Science Quarterly, 36 (3), 421-458.

Baihaqi, I., Sohal, A.S., 2013. The impact of information sharing in supply chains on organisational performance: an empirical study. Production Planning \& Control, 24(8-9), 743-758.

Barney, J.B., 2012. Purchasing, supply chain Management and sustained competitive advantage: The relevance of resource-based theory. Journal of Supply Chain Management, 48(2), 3-6.

Barney, J., 1991. Firm resources and sustained competitive advantage. Journal of Management 17(1), 99-120.

Baron, R.M., Kenny, D.A., 1986. The Moderator-Mediator Variable Distinction in Social Psychological Research: Conceptual, Strategic, and Statistical Considerations. Journal of Personality and Social Psychology, 51(6), 11731182.

Barratt, M., Barratt, R., 2011. Exploring internal and external supply chain linkages: Evidence from the field. Journal of Operations Management, 29(5), 514.

Bayo-Moriones, A., Merino-Díaz, J., 2004. Employee involvement: Its interaction with advanced manufacturing technologies, quality management, and inter-firm collaboration. Human Factors Management, 14, 117-134.

Becker, B.E., Huselid, M.A., 1998. High performance work systems and firm performance: A synthesis of research and managerial applications. Research in Personnel and Human Resources Management, 16, 53-101.

Bentler, P.M., 2002. EQS 6 Structural Equations Program Manual. Encino, CA: Multivariate Software, Inc.

Boselie, J.P., Dietz, G., Boon, C., 2005. Commonalities and contradictions in research on human resource management and performance. Human resource management., 15(3), 67-94.

Bowersox, D.J., Closs, D.J., Stank, T.P., 2000. Ten mega-trends that will revolutionize supply chain logistics. Journal of Business Logistics, 21(2), 1-16.

Bowersox, D.J., Closs, D.J., Stank, T.P. 2003. How to master cross-enterprise collaboration. Supply Chain Management Review; 7(4) 18-27

Brown, S., McHardy, J., McNabb, R., Taylor, K., 2011. Workplace Performance, Worker Commitment and Loyalty. IZA Discussion Paper Series n 5447.

Cagliano, R., Caniato, F., Spina, G., 2006. The linkage between supply chain integration and manufacturing improvement programmes. International Journal of Operations and Production Management, 26(3), 282-299. 
Chen, H., Daugherty, P.J., Landry, T.D., 2009. Supply chain process integration: A theoretical framework. Journal of Business Logistics, 30(2), 27-46.

Chin, W., 1988. Issues and opinions on structural equation modelling. Mis Quarterly, 22(1), 7-16.

Cua, K.O., McKone, K.E., Schroeder, R.G. 2001. Relationships between implementation of TQM, JIT, and TPM and manufacturing performance. Journal of Operations Management, 19(6), 675-694.

Danese, P., Romano, P., 2011. Supply chain integration and efficiency performance: a study on the interactions between customer and supplier integration. Supply Chain Management: An International Journal, 16(4), 220-230.

Danese, P., Romano, P., 2013. The moderating role of supply network structure on the customer integration-efficiency relationship. International Journal of Operations \& Production Management, 33(4), 372 - 393.

Danese, P., Romano, P., Formentini, M., 2013. The impact of supply chain integration on responsiveness: The moderating effect of using an international supplier network. Transportation Research Part E: Logistics and Transportation Review, 49(1), 125-140.

Darmawan, I.G.N., Keeves, J.P., 2006. Suppressor variables and multilevel mixture modelling. International Education Journal, 7(2), 160-173.

Defee, C.C., Williams, B., Randall, W.S., Thomas, R., 2010. An inventory of theory in logistics and SCM research. The International Journal of Logistics Management, 21(3), 404 - 489.

Den Hartog, D.N., Boselie, P., Paauwe, J., 2004. Performance Management: A Model and Research Agenda. Applied Psychology: An International Review, 53(4), 556-569.

deSarbo, W., Di Benedetto, A., Song, M., Bloch, H.V., 2007. A Heterogeneous Resource Based View for Exploring Relationships Between Firm Performance and Capabilities. Journal of Modelling in Management, 2(2), 103-130

Devaraj, S., Krajewski, L., Wei, J.C., 2007. Impact of eBusiness technologies on operational performance: The role of production information integration in the supply chain. Journal of Operations Management, 25(6), 1199-1216.

Dooley, R.S., Fryxell, G.E., 1999. Attaining decision quality and commitment from dissent: the moderating effects of loyalty and competence in strategic decision-making teams. Academy of Management Journal, 42(4), 389-402.

Dow, D., Samson, D., Ford, S., 1999. Exploding the myth: do all quality management practices contribute to superior quality performance? Production and Operations Management, 8(1), 1-27.

Droge, C., Jayaram, J., Vickery, S.K., 2004. The effects of internal versus external integration practices on time-based performance and overall firm performance. Journal of Operations Management, 22(6), 557-573.

Droge, C., Vickery, S.K., Jacobs, M.A., 2012. Does supply chain integration mediate the relationships between product/process strategy and service performance? An empirical study. International Journal of Production Economics, 137(2), 250-262.

Dyer, J.H., Singh, H., 1998. The relational view: cooperative strategy and sources of interorganizational competitive advantage. Academy of Management Review, 23(4), 660-679.

Elorza, U., Aritzeta, A., Ayestaran, S., 2011. Exploring the black box in Spanish firms: the effect of the actual and perceived system on employees' commitment and organizational performance. International Journal of Human Resource Management, 22(7), 1401-1422.

Eng, T.Y., 2006. An investigation into the mediating role of cross-functional coordination on the linkage between organizational norms and SCM performance. Industrial Marketing Management, 35 (6), 762-773.

Fabbe-Costes, N. and Jahre, M., 2008. Supply chain integration and performance: a review of the evidence. The International Journal of Logistics Management, 19(2), 130-154.

Fawcett, S.E., Magnan, G.M., 2002. The rhetoric and reality of supply chain integration. International Journal of Physical Distribution \& Logistics Management, 32(5), 339-361.

Fawcett, S.E., Magnan, G.M., McCarter, M.W., 2008 Benefits, barriers, and bridges to effective supply chain management. Supply Chain Management: An International Journal 13(1), 35-48.

Fawcett, S.E., Magnan, G.M., Ogden, J.A., 2007. Achieving World-Class Supply Chain Collaboration: Managing the Transformation. Institute for Supply Management, Tempe, AZ.

Fields, D.L., 2002. Taking the measure of work: A guide to validated scales for organizational research and diagnosis. SAGE Publications, Incorporated.

Fine, C.H., 1998. Clockspeed. The Winning Industry Control in the Age of Temporary Advantage. Reading, MA: Perseus Books.

Fisher, S.L., Graham, M. E., Vachon, S., Vereecke, A., 2010. Guest Editors' Note: Don't miss the boat: Research on HRM and supply chains. Human Resource Management, 49, 813-828. doi: 10.1002/hrm.20386

Flynn, B.B., Huo B., Zhao X., 2010. The impact of supply chain integration on performance: A contingency and configuration approach, Journal of Operations Management, 28, 58-71.

Flynn, B.F., Sakakibara, S., Schroeder, R.G., 1995. Relationship between JIT and TQM. Practices and Performance. Academy of Management Journal, 38(5), 1325-1360.

Forza, C., 2002. Survey research in operations management: a process-based perspective. International Journal of Operations \& Production Management, 22(2), 152 - 194.

Frohlich, M.T., Westbrook, R., 2001. Arcs of integration: An international study of supply chain strategies. Journal of Operations Management, 19(2), 185-200.

Germain, R., Iyer, K., 2006. The Interaction of Internal and Downstream Integration and its Association with Performance. Journal of Business Logistics, 27(2), 29-52. 
Gimenez, C., Ventura, E., 2003. Supply Chain Management as a competitive advantage in the Spanish grocery sector. International Journal of Logistics Management, 14(1), 77-88.

Gimenez, C., Ventura, E., 2005. Logistics-production, logistics-marketing and external integration, their impact on performance. International Journal of Operations \& Production Management, 25(1), 20-38.

Giunipero, L.C., Hooker, R., Joseph-Matthews, S., Yoon, E., Brudvig, S., 2008. A decade of SCM literature: past, present and future implications. Journal of Supply Chain Management: A Global Review of Purchasing \& Supply, 44(4), 66-86.

Gowen III, C.R., Tallon, W.J., 2003. Enhancing supply chain practices through human resource management. Journal of Management Development, 22(1), 32-44.

Guest, D., Conway, N., 2011. The impact of HR practices, HR effectiveness and a 'strong HR system' on organizational outcomes: a stakeholder perspective. International Journal of Human Resource Management, 22, 1686-1702.

Guest, D.E., 2001. Human resource management: When research conforts theory. International Journal of Human Resource Management, 127(7), 1092-1106.

Gundlach, G.T., Achrol, R.S., Mentzer, J.T., 1995. The structure of commitment in exchange. Journal of Marketing, 59, 78-92.

Hair, J. F., Anderson, R.E., Tatham, R.L., Black, W.C., 1995. Multivariate data analysis. New Jersey: Prentice Hall.

Halldorsson, A., Larson, P.D., Poist, R.F., 2008. Supply chain management: a comparison of Scandinavian and American perspectives. International Journal of Physical Distribution \& Logistics Management, 38(2), $126-42$.

Handfield, R.B., Nichols, E.L., 2002. Supply Chain Redesign - Transforming Supply Chains into Integrated Value Systems. London: Prentice-Hall.

Harrison, A., Van Hoek, R., 2005. Logistics Management and Strategy. Pearson Education.

Hertz, S., 2001. Dynamics of alliances in highly integrated supply chain networks. International Journal of Logistic: Research \& Applications, 4(2), 237-256.

Holmberg, S., 2000. A systems perspective on supply chain measurements. International Journal of Physical Distribution \& Logistics Management, 30(10), 847-68.

Howell, D.C., 2010. Fundamental Statistics for the Behavioral Sciences, Wadsworth Publishing.

Huo, B., 2012. The impact of supply chain integration on company performance: an organizational capability perspective. Supply Chain Management: An International Journal, 17(6), 596 - 610.

Jin, Y.H., Fawcett, A.M., Fawcett, S.E., 2013. Awareness is not enough: Commitment and performance implications of supply chain integration. International Journal of Physical Distribution \& Logistics Management, 43(3), 205 - 230.

Kahn,K.B., Mentzer,J.T., 1996. Logistics and interdepartmental integration. International Journal of Physical Distribution \& Logistics Management, 26(8), 6-14.

Katou, A., 2011. Test of a causal Human Resource Management-Performance Linkage Model: Evidence from the Greek manufacturing sector. Int. Journal of Business Science and Applied Management, 6(1), 16-29.

Ketchen, D.J., Hult, T.M., 2007. Bridging organization theory and supply chain management: the case of best value supply chains. Journal of Operations Management, 25(2), 573-80.

Kim, D.Y., 2013. Relationship between supply chain integration and performance. Operations Management Research, 6(1-2), 74-90.

Kim, S.W., 2009. An investigation on the direct and indirect effect of supply chain integration on firm performance. International Journal of Production Economics, 119(2), 328-46.

Koufteros, X., Cheng, T. C.E., Lai, K.H., 2007. Black-box and gray box supplier integration in product development: Antecedents, consequences and the moderating role of firm size. Journal of Operations Management, 25 (4), $847-$ 870.

Koufteros, X., Rawski, G. E., Rupak, R., 2010. Organizational integration for product development: The effects on glitches, on-time execution of engineering change orders, and market success. Decision Sciences, 41(1), 49-80.

Koufteros, X., Vonderembse, M., Jayaram, J., 2005. Internal and external integration for product development: the contingency effects of uncertainty, equivocality, and platform strategy. Decision Sciences, 36 (1), 97-133.

Koulikoff-Souviron, M., Harrison, A., 2007. The pervasive human resource picture in interdependent supply relationships. Journal of Operations Management, 27(1), 8-27.

Kuo, Y.-K., 2013. Organizational commitment in an intense competition environment. Industrial Management \& Data Systems, 113(1), 39-56.

Lambert, D.M., Cooper, M.C., Pagh, J.D., 1998. Supply chain management: Implementation issues and research opportunities. The International Journal of Logistics Management, 9(2), 1-19.

Leuschner, R., Rrogers, D.S., Charvet, F.F., 2013. A meta-analysis of supply chain integration and firm performance. Journal of Supply Chain Management, 49(2) 34-57.

Li, G., Yang, H., Sun, L., Sohal, A.S., 2009. The impact of IT implementation on supply chain integration and performance. International Journal of Production Economics, 120(1), 125-138.

Liu, G., Shah, R., Schroeder, R.G., 2012. The relationships among functional integration, mass customization, and firm performance. International Journal of Production Research, 50(3), 677-690.

Marin-Garcia, J. A., Alfalla-Luque, R., Medina-López, C., 2013. Supply Chain Integration Scales Validation and Benchmark Values. Journal of Industrial Engineering and Management, 6(2), 423-440.

Marin-Garcia, J. A., 2013. What do we know about the relationship between High Involvement Work Practices and Performance? Working Papers on Operations Management, 4(2), 01-15. 
Marin-Garcia, J.A., Bonavia, T., Pardo, M., 2009. Los Sistemas Productivos, el Aprendizaje Interno y los Resultados del Área de Producción de Baldosas-Cerámicas. Información Tecnológica, 20(1), 39-51.

McCarter, M., Fawcett, S., Magnan, G., 2005. The effect of people on the supply chain world: some overlooked issues. Human Systems Management, 24(2005), 197-208.

Mello, J.E., Stank, T.P., 2005. Linking firm culture and orientation to supply chain success. International Journal of Physical Distribution \& Logistics Management, 35, 542-554.

Menon, S.T., 2012. Human resource practices, supply chain performance, and wellbeing. International Journal of Manpower, 33(7), 769-785.

Mentzer, J.T., 2004. Fundamentals of Supply Chain Management. Twelve Drivers of Competitive Advantage. USA: Sage Publications.

Mentzer, J.T., DeWitt, W., Keebler, J.S., Min, S., Nix, N.W., Smith, C.D., Zacharia, Z.G., 2001. Defining supply chain management. Journal of Business Logistics, 22(2), 1-24.

Meyer, J.P., Allen, N.J., Smith, C.A., 1993. Commitment to organizations and occupations: Extension and test of a three-component conceptualization. Journal of Applied Psychology, 78(4), 538-551.

Miles, R.E., Snow, C.C., 1978. Organizational Strategy, Structure and Process. McGraw-Hill, New York.

Miller, D., Shamsie, J., 1996. The resource based view of the firm in two environments: the Hollywood film studios from 1936-1965. Academy of Management Journal, 39 (3), 519-543.

Min, S., 2001. Inter-functional coordination in supply chain management. In: J.T. Mentzer, ed. Supply chain management. Thousand Oaks, CA: Sage, 371-389.

Mowday, R., Steers, R.M., 1979. The measurement of organizational commitment. Journal of Vocational Behavior, 14, 224-227.

Moynihan, L.M., Gardner, T.M., Park, H.J., Wright, P.M., 2001. HR practices and customer satisfaction: The mediating link of commitment (CAHRS Working Paper \#01-14). Ithaca, NY: Cornell University, School of Industrial and Labor Relations, Center for Advanced Human Resource Studies. http://digitalcommons.ilr.cornell.edu/cahrswp/77

Nishii, L., Lepak, D., Schneider, B., 2008. Employee attributions of the 'why' of HR practices: Their effects on employee attitudes and behavior and customer satisfaction. Personnel Psychology, 61, 503-545.

Nyaga, G.N., Whipple, J.M., Lynch, D.F., 2010. Examining supply chain relationships: Do buyer and supplier perspectives on collaborative relationships differ? Journal of Operations Management, 28, 101-114.

Olavarrieta, S., Ellinger, A.E., 1997. Resource-based theory and strategic logistics research. International Journal of Physical Distribution \& Logistics Management, 27(9/10), 559-87.

Pagell, M., 2004. Understanding the factors that enable and inhibit the integration of operations, purchasing and logistics. Journal of Operations Management, 22(5), 459-487.

Pandey, P., Bhattacharyya, S., Kaur, A., 2012. Exploring the role of HR practices in supply chain. Journal of Advances in Management Research, 9(1), 113-123.

Patterson, M., Rick, J., Wood, S., Carroll, C., Balain, S., Booth, A., 2010. Systematic review of the links between human resource management practices and performance. Prepress Projects Limited.

Paul, A.K., Anantharaman, R.N., 2003. Impact of people management practices on organizational performance: analysis of a causal model. International Journal of Human Resource Management, 14, 1246-1266.

Peteraf, M.A., 1993. The cornerstones of competitive advantage: a resource-based view. Strategic Management Journal, 14(3), 179-191.

Porter, ME., 1986. Competitive Advantage. Free Press: New York.

Samad, S., 2013. Assessing the Contribution of Human Capital on Business Performance. International Journal of Trade. Economics and Finance, 4(6), 393-397.

Sanders, N.R., 2008. Pattern of information technology use: the impact on buyer-suppler coordination and performance. Journal of Operations Management, 26(3), 349-367.

Schroeder, R.G., Flynn, B.B., 2001. High Performance Manufacturing - Global Perspectives. Wiley, New York, NY.

Schroeder, R.G., Bates, K.A., Junttila, M.A., 2002. A resource-based view of manufacturing strategy and the relationship to manufacturing performance. Strategic. Management Journal, 23,105-117.

Schumacker, R.E.; Lomax, R.G., 1996. A Beginner's Guide to Structural Equation Modeling. Mahwah, NJ: Lawrence Erlbaum.

Sezen, B., 2008. Relative effects of design, integration and information sharing. Supply Chain Management: An International Journal, 13(3), 233-40.

Shub, A.N., Stonebraker, P.W., 2009. The human impact on supply chains: evaluating the importance of soft areas on integration and performance. Supply Chain Management: An International Journal, 14(1), 31-40.

Sofyalığlu, C., Öztürk, Ş., 2012. Meta Analysis of the Relationship between Supply Chain Integration Dimensions and Firm Performance. European Journal of Economics, Finance and Administrative Sciences, 52, 99-119.

Song, M., Thieme, J., 2009. The role of suppliers in market intelligence gathering for radical and incremental innovation. Journal of Production Innovation Management, 26(1), 43-57.

Stank, T.P., Keller, S.B., Daugherty, P.J., 2001. Supply chain collaboration and logistical service performance. Journal of Business Logistics, 22(1), 29-48.

Swink, M., Narasimhan, R., Wang, C., 2007. Managing beyond the factory walls: Effects of four types of strategic integration on manufacturing plant performance. Journal of Operations Management, 25(1), 148-164. 
Thun, J., 2010. Angles of integration: An empirical analysis of the alignment of internet-based information technology and global supply chain integration. Journal of Supply Chain Management, 46(2), 30-44.

Turkulainen, V., Ketokivi, M., 2012. Cross-functional Integration and Performance - What are the Real Benefits? International Journal of Operations \& Production Management, 32(4), 447-467.

Van Bruggen, G.H., Lilien, G.L., Kacker, M., 2002. Informants in organizational marketing research: why use multiple informants and how to aggregate responses. Journal of Marketing Research 39 (4), 469-478.

Van der Vaart, T., Van Donk, D.P., 2008. A critical review of survey-based research in supply chain integration. International Journal of Production Economics, 111(1), 42-55.

Vanichchinchai, A., 2012. The relationship between employee involvement, partnership management and supply performance: Findings from a developing country. International Journal of Productivity and Performance Management, 61(2), 157-172.

Vanichchinchai, A., Igel, B., 2011. The impact of total quality management on supply chain management and firm's supply performance, International Journal of Production Research, 49(11), 3405-3424.

Vickery, S.K., Jayarm, J., Droge, C., Calantone, R., 2003. The effects of an integrative supply chain strategy on customer service and fianancial performance: an analysis of direct versus indirect relationships. Journal of Operations Management, 21, 532-539.

Wernerfelt, B., 1984. A Resource-Based View of the Firm. Strategic Management Journal, 5(April-June), 171-80.

Whipple, J.D., Lynch, D.F., Nyaga, G.N., 2010. A buyer's perspective on collaborative versus transactional relationships. Industrial Marketing Management, 39, 507-518.

Wong, C.Y., Boon-itt, S., 2008. The influence of institutional norms and environmental uncertainty on supply chain integration in the Thai automotive industry. International Journal of Production Economics, 115(2), 400-410.

Wu, I.L., Chuang, C.H., Hsu, C.H., 2014. Information sharing and collaborative behaviors in enabling supply chain performance: A social exchange perspective. International Journal of Production Economics, 148, $122-132$.

Young, S., Choi, J.N., 2011. The Effects of Human Resource Development on Operational and Financial Performance of Manufacturing Companies: A Large-Scale, Longitudinal Analysis. The Institute for Research on Labor and Employment, UCLA. http://escholarship.org/uc/item/5xz8p7bk

Zhao, L., Huo, B., Sun, L., Zhao, X., 2013. The impact of supply chain risk on supply chain integration and company performance: a global investigation. Supply Chain Management: An International Journal, 18(2), 115 - 131.

Zhao, X., Huo, B., Selen, W., Yeung, J.H.Y., 2011. The impact of internal integration and relationship commitment on external integration. Journal of Operations Management, 29(1-2) 17-32. 